This is the accepted version of the paper published in the European Journal of Archaeology. Full citation: Harris, S. 2012. From the Parochial to the Universal: Comparing Cloth Cultures in the Bronze Age. European Journal of Archaeology, 15, (1) 61-97

DOI:10.1179/1461957112Y.0000000006

Link: http://www.tandfonline.com/doi/full/10.1179/1461957112Y.0000000006\#.V1WjSk32aqk

Publishers website: www.maneypublishing.com

\title{
From the parochial to the universal: comparing cloth cultures in the Bronze Age
}

\section{Susanna Harris}

\begin{abstract}
The aim of this research is to compare the cloth cultures of Europe and Egypt in the Bronze Age and New Kingdom. The comparison focuses on the fourteenth century BC and includes four geographically separate areas including the oak coffin burials of southern Scandinavia, the Hallstatt salt mines of central Europe, the Final Palace period of Crete and the tombs and towns of the later eighteenth Dynasty of Egypt. The comparative approach can bring insights even when applied to unconnected cultures or regions. However, in this study I concentrate on a restricted chronological period and areas that were connected, directly or indirectly, by widespread networks of trade or exchange. The concept of cloth cultures is used to include both textiles and animal skins as these were closely related materials in the prehistoric past. Information is gathered according to the following categories: raw materials including textile fibre and species of skins, fabric structure and thread count (only for textiles), decoration and finish, use and context. From this study it is possible to recognize the universally shared principles of cloth cultures and the great versatility and creativity in the regional cloth cultures of the Bronze Age.
\end{abstract}

Keywords: textiles, animal skins, Bronze Age, cloth culture, clothing.

\section{Introduction}

This research investigates and compares the cloth cultures of Europe and Egypt in the Bronze Age and New Kingdom ${ }^{1}$ focusing on the fourteenth century BC. The concept of cloth cultures is used to include both textiles and animal skins as these were closely related materials in the prehistoric past. There are now many excellent research results in the field of textiles (Andersson Strand et al. 2010) with especially strong regional and diachronic studies (for example Barber 1991;Bender Jørgensen 1992;Broholm and Hald 1940;Grömer 2007,2010;Kemp and Vogelsang-Eastwood 2001). In addition, the importance of textiles is well recognized in syntheses of the period (for example Harding 2000:254-264) and in the context of clothing (Kristiansen and Larsson 2005:271-3; Sørensen 1997; Vogelsang-Eastwood 1993). Animal skin products whether leathers or furs are less frequently studied than textiles, but there are a growing number of good quality data sets as well as chronological and regional studies (for example Aner and Kerstein 1973ff; Barth 1992; DrielMurray 2000; Ryder 1988; Veldmeijer 2010). The integration of animal skin technology in general syntheses and their cross cultural comparison is less well investigated.

Through considering cloth cultures rather than only textiles, this paper brings together the evidence for textile and animal skins and questions the relationship between them in the Bronze Age. By focusing on a short period, this study seeks to compare cloth cultures that existed at the same time, rather than development over time. The originality of this research is therefore to bring these material together both within regional studies and between them. A study like this is only possible because of the accumulation of regional data collected and published by many specialists and takes advantace of a remarkably fortunate situation in the archaeological record, whereby the fourteenth century $\mathrm{BC}$ and the few decades preceeding and following contain a number of sites with well 
preserved organic material and other sources of evidence. The evidence I will use and describe in the main body of the paper comes from four geographically separate areas and includes the Period II oak coffin burials of southern Scandinavia, the Hallstatt salt mines of central Europe, the Final Palace period of Crete (Late Minoan LMII-LMIIIA) and the tombs and towns of the later eighteenth Dynasty of Egypt. In addition to published sources this research has been supplemented by study visits in Europe and Egypt. These examples are dated using absolute dating schemes that provide a good case for contemporaneity, although not all dating issues are fully resolved notably the archaeological periods on Crete and their correlation to Egyptian dating schemes (Manning 1999, 2006; Hornung et al. 2006c; Warren 1996).

By taking a broad geographical view, I have chosen evidence which on the face of it appears to be scattered and unrelated. However, as other lines of archaeological evidence have demonstrated, the fourteenth century BC and several centuries preceding are a time of wide ranging interactions in Europe and around the Mediterranean (Sherratt 1993; Harding 2000:ch.13; Kristiansen \& Larsson 2005). Therefore, despite being distinct and separate with different cultural trajectories, these are not isolated areas and were interconnected, whether directly or indirectly. This is important for understanding how cultural attitudes to these materials varied between cloth cultures, as well as highlighting similarities.

\section{Cloth culture}

The concept of cloth culture is based on the idea that all societies use cloth-type materials, but the way they do this is specific to each culture. By cloth-type materials, or more simply 'cloth', I refer to those flexible, thin sheets that can be wrapped, shaped and folded and are used to clothe, cover and contain (Harris 2008; Harris 2010:30). In the Bronze Age textiles and animal skins (leather and fur) were significant materials and technologies used to produce cloth. The term cloth culture follows research by social anthropologist Brigitta Hauser-Schäblin (1996). She compared the textile cloth cultures of Indonesia and to the Pacific non-cloth cultures of bark cloth, looped billum and curtains of fronds to demonstrate the culturally embedded selection of appropriate materials and rejection of inappropriate materials and to show how technology is embedded in wider cultural beliefs and practices (Hauser-Schäublin 1996). From a theoretical perspective, this comparison draws on theories of style in technology (Lechtman 1975;Stanley Smith 1970) and technological choices (Lemonnier 1993; Tite and Sillar 2000). These question why techniques, materials and material culture exist in the form they do and answer this not only by invoking necessity, raw material availability and technical knowledge, but also aspects of cultural identity and related aspects such as aesthetics, traditions and values.

Cloth cultures is not the same as clothing cultures, where the focus is on clothing (see Burnham 1973; Pritchard 2006). Certainly, cloth (whether from woven textiles, animal skins or other materials) is the essential raw material for clothing. As clothing, cloth has a unique role in costume and therefore forming, communicating and visualising social identities (Barnes and Eicher 1993;Eicher 1995; Sørensen 1997; Wobst 1977). However costume and clothing type is not the only means by which identity is formed through cloth and indeed cloth is not only used for clothing. It is this component material 'cloth' and its cultural expression in the fourteenth century BC that I am interested in here.

\section{Archaeological Background}

Chronological and regional studies demonstrate that by the Bronze Age, producing cloth by weaving on a loom using linen fibres had been known and practiced for several thousand years in much of the Near East, southern and central Europe (Barber 1991:11-5,ch.3; Allgrove-McDowell 2003:31-2; Bender Jørgensen 2003:61-2; Rast-Eicher 2005; Wild 2003:43-4). The use of wool fibres is attested from at least the mid third millennium BC, as an aspect of the "Secondary Products Revolution" (Sherratt 1981:159,180-1; McCorriston 1997). Weaving was the main textile technique 
and will be the focus of this research. Minor cloth types such as netting, sprang and plaiting are known from a number of contexts but will not be investigated here (Wild 2003:24; Bender Jørgensen 1992:14). Dyeing, here referring to any mode used for colouring cloth, is known from a number of sites Bronze Age of Europe (Burke 2010:34-9; Hofmann-de Keijzer and van Bommel 2009:113) and New Kingdom of Egypt (Vogelsang-Eastwood 1992:36). Researchers have investigated the spatial distribution of textile fibres and weaving techniques (especially Barber 1991; Bender Jørgensen 1992).

While textile studies have flourished, the study of animal skins in prehistory has developed more slowly and remains a smaller field. It has been enhanced since the discovery of preserved skins in frozen alpine environments (Schlumbaum et al. 2010; Spindler 1995; Winiger 1995). These have led to a re-evaluation of vegetable tanning in Europe and Egypt, which is now thought to be unlikely before the Classical period (Driel-Murray 2000:299-305; Groenman-van Waateringe et al. 1999). By contrast in south, central and northern Europe, the implicit assumption seems to be that in contrast to textiles, animal skin technology in the Bronze Age is static or of declining importance. One area of curiosity is the rarity of preserved animal skin clothing. Various suggestions for its diachronic demise or niche use have been suggested, such as the role of certain animal skin garments in rituals and ceremony (Sakellaraki in Kontorli-Papadopoulou 1996:91), as indicative of a social 'other' (Davis and Bennet 1999) or declining in importance with the advent of wool textiles (Rast-Eicher 2005:124). By contrast, in $18^{\text {th }}$ Dynasty New Kingdom Egypt archaeologists recognize that animal skin products were more widely used than earlier periods, possibly due to the introduction of new weapon technology (Driel-Murray2000:309-10).

The archaeological evidence points to the fourteenth century $\mathrm{BC}$ as a time of wide ranging interactions. In the east Mediterranean goods were transported via sailing ship as demonstrated by the presence of foreign artefacts and vividly illustrated by the rich range of raw material and finished goods in the cargo of the Ulu Burun wreck dating to the fourteenth century BC (Broodbank 2009,704-7). Written sources of this time, such as the Amarna letters, document international gift exchange among the Egyptian and Mediterranean elite, including the exchange of fine textiles (Knapp 1991 cited in Burke 2010,40-1). Copper and tin must have been traded into metal poor Scandinavia, potentially from the metal-rich regions of central Europe (Vandkilde 2004, 72). The source for these metals after $1600 \mathrm{BC}$ was most likely the east Alpine copper sources and Bohemia for tin (Sherratt 1993:31). More generally, connections between southern Scandinavia and Central Europe are indicated by the shared social habits, ideas and fashions of the "Tumulus Culture" (Vandkilde 2004:73-4). The presence of Baltic amber in Greece identifies goods from the north being taken south (Harding 2000:190;1984). In Egypt and the Mediterranean people of neighbouring regions met and interacted through warfare, the presentation of tribute or gifts to foreign dignitaries, sea borne trade and intermarriage (for example Bietak 2007; Kendall 2007; Steel 2007; Tyson Smith 2007,; Wilkinson 2007). Iconographic sources in Egypt and on the Greek islands represent regional stereotypes though cloth, costume and phenotypic traits such as skin colour (Tyson Smith 2007:220-1; Morgan 1988:118-20). The relationship between north and central Europe, the Mediterranean and Near East have been perceived through models such as a Bronze Age core and periphery in a world system (Sherratt 1993), major centres and local zones (Harding 2000:ch.13) or symbolic transmissions (Kristiansen \& Larsson 2005). The people of the fourteenth century BC were influenced by their near neighbours and more distant connections, whether directly or indirectly. Therefore the context of material culture, such as cloth culture, needs to be considered in terms of local and universal themes.

\section{Method}

The comparison will be limited to approximately 100 years, centring on the fourteenth century BC (1400-1300 BC) and where necessary drawing from a longer time frame of 1450-1250 BC due to the nature of the evidence or dating precision. A century sets the evidence in a time-frame of three 
to four generations. For the archaeologist, one important advantages of following the social anthropological approach of comparing contemporary cultures over a large geographical area, is that is provides a much larger pool of comparative data on this topic than is usually available. The comparative approach can bring insights even when applied to unconnected cultures or regions. However, in this study I concentrate on a restricted chronological period and areas that were connected, directly or indirectly, by widespread networks of trade. The benefit is that new insights for Bronze Age material are gained from cultures that existed within the same time frame, rather than drawing on analogy or ethnography. This brings added significance to the patterns of similarities and differences in the cloth cultures of the different areas.

The comparison of cloth cultures will focus on evidence for textiles and animal skins. Information will be gathered according to the following categories: raw materials including textile fibre and species of skins, fabric structure and thread count (only for textiles), decoration and finish, use and context. Identification of textile fibres (Walton and Eastwood 1988,3-4) and animal skin species (Groenman-van Waatering 1992, Haines 1991) determines the raw materials, and evidence will be considered in the light of differential preservation. Fabric structure describes the technical interlacing of threads (Emery 1966,xv) and together with thread count, decoration and finish has implications for material properties and appearance (Chandler 1995,119-28,Hammarlund 2004). The textile structures are described in Table 1; variations are described in the text. The thread count is the number of threads lying parallel to each other in each system (warp or weft) and is averaged over one centimetre (Emery 1966:76; Walton and Eastwood 1988,4). Thread count relates in part to the fineness and coarseness of textiles. As a general principle, the more threads per centimetre, the finer the cloth. However, variations in the density and thickness of thread can create further visual and material differences (Chandler 1995:ch.6;Hammarlund 2004). Decoration and finish describes surface treatment. Pattern may be woven into textiles, as stripes or areas of colour. Either animal skins or textiles may be decorated with embroidery, applique, painting, beading, or dye. In addition, animal skins may be finished by retaining the hair (described as fur or hair on) or removing the hair and can be decorated with raised relief, cutwork or scoring. The role of textiles and animal skins is used to describe the way these materials were used and includes observation of archaeological context, for example in burials or in working environments. These categories focus on the type, context and use of the materials rather than production and have been selected as they can be compared across much of the dataset.

The time period of this study includes a number of exceptionally well preserved sites and artefacts, thereby offering a remarkable opportunity to compare cloth cultures. However, the evidence is scattered, includes different preservation environments (wet, dry, salt, acidic) and contexts (burials, iconography, settlement sites). Primarily, the poor preservation of these highly perishable materials means that the samples are frequently degraded and fragmentary, especially in comparison with inorganic materials such as pottery or metals. Certainly this increases the likelihood of missing information and makes it difficult to be certain of the absence of particular techniques or materials. Differential preservation is an issue, especially in the acidic soils of southern Scandinavia. Dye and colour is especially vulnerable to degradation. For the most part, preserved archaeological textiles and animal skins cannot be sourced to their area of origin therefore in this paper these are treated as local in terms of deposition rather than production origins.

\section{Cloth cultures - the evidence}

The evidence is presented below in four sections, ordered geographically from north to south.

\section{Southern Scandinavia}

The southern Scandinavian cultural group is situated in Denmark, the provinces of Scania and Halland in Sweden, Schleswig and Holstein in North Germany (Bender Jørgensen 1986,289, Vankilde 2004,72). Evidence for textiles and skins is preserved in the oak coffin burials of men, 
women and children who were buried beneath earth barrows and has been well described (Aner \& Kerstein 1973ff, Bender Jørgensen 1986, Bender Jørgensen 1992, Boye 1986/1896, Broholm \& Hald 1940, Randsborg 2006). Typologically many of the textile rich burials date to Montelius Bronze Age Period II, which ends around 1300 BC (Vandkilde 2004,73). Dendrochronology dating of a number of well-preserved oak coffins show that 19 fall between the years 1391-1344 cal. BC (Christensen 2006:181, Vandkilde, Rahbek, \& Rasmussen 1996:191). At this time farming societies cultivated plants and kept herds of animals (Vandkilde 2004,77,Jensen 1982,132). They lived in large, two or three-aisled long houses accompanied by outhouses, a pattern that could represent single farmsteads or small clusters of independent households (Jensen 1982,148-9;Rasmussen and Adamsen 1993,136-8). The evidence from the grave goods of the barrow burials has been used to demonstrate that this was a time of increasing social inequality, which may have been organized as chiefdoms, a warrior aristocracy or tribal system (views summarized in Vandkilde 1996,22-3, fig.278).

The textiles from the southern Scandinavian oak coffin burials are made from fine sheep's wool (Ryder 1988, 2005:123). There are no preserved linen textiles, neither is their archaeobotanical evidence for flax cultivation in Denmark at this time, it is only known in the later Bronze Age (Henriksen 2009). The simple fabric structure called plain weave is by far the most common (Bender Jørgensen 1986:289), some textiles are finished with a fringe. Many textiles were fulled then cut (for example Broholm and Hald 1940,17,27) a technique which meant they resisted fraying. The majority of textiles are have an average thread count of only 3-6 threads per centimetre of weaving, and only a few with 6 threads per cm or more (Bender Jørgensen 1986:18,fig.6,290-2). The result is a thick and coarse but flexible, soft fabric (Figure 1).

In the burials with well-preserved clothing and blankets (or shrouds) it is possible to see that textiles were woven in large pieces. The blanket spread over the young woman's body found at Egtved measures 250cm long and 170-190cm wide (Broholm \& Hald 1940:82). A similar blanket from a man's grave at Muldbjerg measures $130 \mathrm{~cm}$ by $211 \mathrm{~cm}$ (Broholm \& Hald 1940:22). The textiles include a number of long, narrow repp bands that were used as belts. Some belts end in fringes that form tassels such as a man's belt from Trindhøj and Egtved (Broholm \& Hald 1940:33-6,86). An elaborate repp belt was found in a woman's grave at Borum Eshøj, over $250 \mathrm{~cm}$ and just $3 \mathrm{~cm}$ wide and is woven to emphasize a central stripe of darker colour (Broholm \& Hald 1940:73). A variation of repp forms the waist band of the famous corded skirt from Egtved. Here the skirt cords are formed by a fringe extended along the length of the repp band (Broholm \& Hald 1940:86-7) (Figure 2 ). This is the only complete corded skirt, but textile fragments of several others have been identified (Bender Jørgensen 1986:289). Rows of small bronze tubes are believed to mark the hem of similar skirts in graves where no or few textiles survive (Broholm and Hald 1940:150; Randsborg 2011:149-52, tab.6) .

Pile was sewn onto the surface of a few plain weave textiles, creating a furry surface effect (Broholm \& Hald 1940:29). A coarse example of pile is found on the cloak from a man's grave at Trindhøj, a Period III woman's grave at Melhøj (dated 1200BC) and a grave from Emmedsbo Mark, Djursland (Bender Jørgensen 1986:291,1992,56-7). Fine pile of 2-3 wool fibre twisted and knotted together was stitched onto the surface of domed hats which are found in a number of men's graves (Bender Jørgensen 1986:289; Tidow 1992). The waterlogged conditions inside the southern Scandinavian coffins have discoloured everything and most of the textiles are now dark brown. Research suggests that the sheep fleece were mainly pigmented brown with white underbelly, therefore providing naturally dark and light wool (Ryder 1988:140; Ryder 2005:124,Tab.22.1). White textiles were rare, a large beige (originally white) blanket was found in the man's burial at Trindhøj (Broholm \& Hald 1940:37). Dye analysis has not yet been carried out on the burial textiles. Surface embroidery is rare examples are known from Skrydstrup, Melhøj and Emmedsbo Mark (Broholm \& Hald 1940:97; fig.138, Bender Jørgensen et al. 1982:56, Cat.D.1:98 and 140, figs 
$12 \& 13)$. Although completely discoloured, the embroidery stitches are similar to the visibly coloured embroidery on the textiles found with a bog body from Emmer-Erfscheidenveen, the Netherlands (Comis 2003), dated between 1500-1100 BC (Period II/III) (Bergerbrant 2007:54).

The textiles in the southern Scandinavian oak coffin burials were used for clothing and blankets. Clothing includes women's blouses, skirts, socks and corded skirts, men's kilts, caps, socks, wraparounds and cloaks (Broholm \& Hald 1940,ch.2, terminology of clothing from Bergerbrant 2007, ch 4). Wear shows that the burial clothing was worn by people in life (Ekildsen \& Lomborg 1977:21 cited in Bergerbrant 2007:49). Evidence for textiles from non-burial contexts is scarce except for the textile fragments found with the Emmer-Erfscheidenveen bog body (Comis 2003) and several Swedish rock carvings show the outline of garments and shoe soles (Malmer 1981:54-5,59-65).

The largest animal skin remains are cow skins (retaining the hair) on which the men, women and children's bodies were laid or wrapped (Boye 1986/1896; Broholm \& Hald 1940; Randsborg 2006:24) (Figure 2). Skins from burials are generally badly preserved but what remains show they were used in a number of ways. For example, the man at Muldbjerg was wrapped in a cow skin shroud, has a leather belt to fasten his textile gown and a fur-lined sword sheath (Broholm \& Hald 1940:19-26). The man buried at Guldhøj (grave A) was wrapped in a cow-skin shroud, the child's burial in the same mound was buried in what is described as a fine black-haired goat skin (Glob 1974:92). The man also had traces of leather footwear and seat of the folding stool accompanying the burial has been identified as otter skin (Broholm \& Hald 1940:42). Small leather remains are found in a number of burials to wrap metal objects such as knives (examples in Aner \& Kern 1973ff). Excluding shoes and straps, no large garments in skins or furs have been found in the burials. Margrethe Hald suggested the cut of the women's blouse originated from patterns for skin clothing (Hald 1980:344-50). One possibility is that skin clothing existed alongside these textile versions, but was either not placed or not preserved in the burials. Skin garments were found with the Emmer-Erfscheidenveen bog body including calf-skin cape, sheepskin hat and a deerskin shoe (Groenman-van Waateringe 1990 cited in Comis 2003:194-5).

\section{Hallstatt, north-eastern Alps}

The most ample evidence for textiles and animal skins in the fourteenth century BC in central Europe comes from the Bronze Age Hallstatt salt mines situated the Hallstatt High Valley in the north-eastern Alps, Austria. The construction timbers in the Christian Tuschwerk mine have been dated with dendrochronology and the end dates range from 1458-1245 BC (Grabner et al. 2007: 6567). Little is known of the social organisation of the miners, their settlements or burials (Reschreiter and Kowarik 2009b,70-1). Log-cabin type constructions (blocbau) outside the mines are dated to the $13^{\text {th }} / 12^{\text {th }}$ centuries BC (Reschreiter and Kowarik 2009a ). Alpine pasturing is known from the nearby Dachstein mountains (Mandl 2009). The mines are contemporary with the end of the Tumulus culture in Central Europe with its standard burial practice of inhumation under mounds (barrows) (Harding 2000,97). These communities practised mixed farming, cultivating crops (cereals, legumes, flax) and raising animals (cattle, sheep, goats, pigs, dogs, horses); in some areas pastoralism and transhumance seem to have been important (Szeverenyi 2004:25-6,30). The grave goods in burial mounds suggest a warrior elite, possibly organized through loose alliances and without centralized leadership (Szeverenyi 2004:29-30).

The mines are a complex of galleries and shafts full of waste left behind by the miners (Reschreiter 2005). In the salty environment, all organic materials are preserved (Reschreiter and Kowarik 2009c). The most recently excavated is the Christian Tuschwerk, a shaft where salt was loaded into bags and carried to the surface via a wooden staircase (Barth 1994:28; Grabner et al. 2006:46; Grömer 2005:31; Reschreiter 2005:12-3). Animal skins, wool and linen textiles are preserved in the salty deposits (Barth 1992; Grömer 2007; Harris 2006). The textiles have recently been studied and published by Karina Grömer whose research will be used here. 
The vast majority of textiles from the Hallstatt salt mines are woven from wool fibres; from a total of 111 textile fragments, just two are from plant fibres that have been identified as linen (Grömer 2007:85). Although now discoloured, the wool fibres have a naturally light pigmentation and the majority are in plain weave (Grömer 2007:87,95, 102). The majority of textiles are what Grömer defines as coarse textiles with 1-5 threads per $\mathrm{cm}$ or fall into a medium fine category at 6-10 threads per $\mathrm{cm}$; a few are finer with between 10-15 (fine) or over 15 (very fine) threads per $\mathrm{cm}$ (Grömer 2010:120, Abb.55) (Figure 3). There are examples of repp textiles, repp bands and repp weaving borders (Grömer 2007:89,100-11). There are three examples of 2/1 twill, one in wool from the Christian Tuschwerk area of the mine and two in linen from the Grünerwerk mining area (Grömer 2007:98). Quite exceptional is $2 / 2$ chevron twill with point repeat, made from fine double wool threads excavated from the Christian Tuschwerk, woven with 18-20 threads per $\mathrm{cm}$ it is also one of the finest textiles from the mines (Grömer 2007:89-99). This is some of the earliest evidence for twill fabric structure in central Europe (Grömer 2009:108). A brocade pattern resembling diamond twill is known from the Early the Bronze Age site of Molina di Ledro, northern Italy (Perini 1970) and a thirteenth century BC twill impression is recorded from Switzerland (Hundt 1974:50 in Bender Jørgensen 1992:104).

A few textiles were dyed. Analysis shows evidence for red, blue and yellow dye components and some were multiple dyed with yellow, red and blue to create dark colours such as brown or black (Grömer 2007:113-5, Grömer 2009:107,Hofmann-de Keijzer and van Bommel 2009:113). As the textiles are only found in rags in the mine it is difficult to determine their use and suggestions are made on the basis of type and context. One suggestion is that coarse textiles with fulled surfaces and reinforced edges found in the Christian Tuschwerk are remains of hauling sacks used to carry the salt to the surface, whereas textiles found in other parts of the mine were possibly the remains of clothing (Grömer 2005:20; Grömer 2009,106).

The species of skins from the Hallstatt salt mines has not been fully analysed. Looking at the Bronze Age and Iron Age skins together, Ryder identified that nearly 90\% of the animal species used for skins were from domestic species, including cattle, goats and sheep; others were possibly from chamois, ibex and small fur-bearing mammals (Ryder 1990:107; 1992,63-4). The preservation of complete, or nearly complete, skin artefacts allows a good interpretation of their use in the mines. A conical hat with tassel, neatly sewn from several pieces of sheepskin and worn with the hair facing inwards is the only complete item of clothing (Ryder 1990:107) (Figure 4). So far, five large carrying sacks have been recovered; these were made from cow skin with the hair side facing outwards, stitched to shape and reinforced with wooden frames (Barth 1992). A number of handleathers have been recovered from the mines. These are pads stitched together from oval pieces of haired animal skins and would have protected the hands (Reschreiter \& Kowarik 2009d:56-7). Numerous skin straps and thongs have been recovered from the mines, some served to stitch together wooden planks to make mining equipment (Harris 2006,73).

Many of the animal skin artefacts are less easy to interpret and suggestions are based on their size, shape and context. Two stitched tubes are interpreted as finger bandages and several larger ones as wrist straps or bracelets (Popa 2009:102). A large pad of two furs roughly stitched together may be a cushion for sitting or kneeling (Harris study visit 2009). There are many skin fragments and rags. The presence of fine stitching and seams, like those used on the conical hat, may suggest they were originally from clothing and contrasts to the large stitching on the hand-leathers and carry sacks associated with mining equipment (Harris et al. 2010). In terms of decorative and visual effects, many of the skins retain their fur including the cow skin carrying sacks, straps, hand-leathers, cushion and numerous fragments. Depending on the species and natural variation in pelage, the fur ranges from dark to light brown, orange-brown and cream (Harris 2006:72, Ryder 1990:107). There 
is only one example of surface decoration on the animal skin artefacts. One of the wrist straps has a zigzag edge and cut-out triangles surrounded by scored lines (Popa 2009:102) (Figure 5).

The skins are recovered in higher quantity and as larger pieces than the textiles. The carry sacks are around $80 \mathrm{~cm}$ tall and with an opening diameter of $35-40 \mathrm{~cm}$ (Barth 1992) and the largest composite sheet of stitched skins recovered measures 108 by $154 \mathrm{~cm}$ (Harris study visit 2004). This contrasts to the textiles where many measure less than $20 \mathrm{~cm}$ maximum height or width and none are larger than $46 \mathrm{~cm}$ (Grömer 2007:389). Whereas whole skin artefacts and fragments were left in the mines, textiles were only left as rags, hence complete textile dimensions are not known from this evidence.

\section{Final Palace period Crete LMII - LMIIIA}

With its large elite residences, officials and thousands of workers receiving rations, Crete was home to a hierarchal society based on agriculture and the production of luxury goods (Fitton 2002:17, 979,Wardle 1994:226-7). At Knossos palace, changes in site use, pottery style and the presence of tablets written in Linear B suggest the previously Minoan palace was under the administrative control of the Mycenaean mainland Greece (Fitton 2002:180,Preston 2008:311-4). The mid fifteenth to sometime in the fourteenth century BC is referred to as the either the Final Palace or Third Palace period ending with the final destruction of Knossos palace, dated between 1375-1350 BC or slightly later (Fitton 2002:180,Preston 2008:310,Preziosi and Hitchcock 1999:1657,Schofield 2007:73,116). Subdivided into different ceramic phases, it is referred to as the Late Minoan (LM), specifically LM II to LM IIIA2 early (Fitton 2002:180,Preston 2008:310-11), these phases are used to date the wall paintings (Immerwahr 1990, Hood 2005). It is the evidence of this phase that will be presented here. The epigraphic evidence from Knossos is dated by archaeological context to LM II, LM IIIA2 (1450-1325) and LM IIIB (1325-1190 BC) (Del Freo et al. 2010:338). Together these sources are referred to as the Knossos archive. The linear B script is considered Mycenaean, reflecting the change in administration (Burke 2010:69). A time of political upheaval, this is also one of the most complex phases of archaeology to understand and date on Crete.

Few preserved textiles are known from mainland Crete and to my knowledge there are no preserved animal skins. However, clothing and cloth artefacts of what appear to be textiles and animal skins are represented on wall painting dating to this period at Knossos Palace and Agia Triada villa (Hood 2005,Immerwahr 1990). As many wall paintings were over-restored care has been taken to refer to the original features. Written evidence for textile fibres come from the Linear B tablets that record palace administration and attest to the importance of wool fibre to supply the weavers of Knossos and other parts of Crete (Killen 2007,52). Evidence on the tablets for linen cloth from flax is less well attested and less clearly interpreted, although the Knossos archive is believed to refer to a number of linen cloths or garments (Burke 2010,77,95, Rougemont 2007,47-8). If linen and wool were the fibres of the palace economy, that does not exclude the use of other raw materials as is demonstrated by the analysis of fibres from a narrow band from the Minoan site of Kastelli, Chania on Crete which have been identified as linen, nettle and goat's hair (Moulhérat \& Spantidaki 2009).

Of the few preserved textiles, plain weave is evident from Mochlos (Möller-Wiering 2006:4). Repp is attested in a narrow band mentioned above from Kastelli, although here the technique is better described as plaiting (Möller-Wiering 2006:2). This band is less than $1 \mathrm{~cm}$ wide and has the up to 10 threads per $\mathrm{cm}$ in the densely worked set (Möller-Wiering 2006:2). The plain weave from Xestè has at least 20 threads per $\mathrm{cm}$ (Moulhérat \& Spantidaki 2007:50). The Linear B tablets refer to a number of textile garments and textiles of different qualities (thick, heavy, finished, unfinished, fine) and many of them were coloured (summary in Burke 2010:74-8; Del Freo et al. 2010,348).

A tiny fragment of plain weave from Xestè 3 in Akrotiri, Santorini Island dated c.1600 BC, provides direct evidence for a variety of decoration techniques, including weaving with supplementary threads (brocade), surface embroidery, seams finished with blanket stitch and a 
knotted fringe (Moulhérat \& Spantidaki 2007:50). The wall paintings depict colourful, patterned textiles with fringes. Stripes, zigzags, quatrefoils and dotted patterns could have been created by using the decorative techniques found on the Xestè 3 textiles, or other techniques such as tapestry weave, bead work, painting and appliqué: some diagonal patterns may represent twill (Barber 1991:317-28; Trnka 2007:128). The female figure called 'La Parisienne' from Knossos is wearing a blue knotted scarf with red strips and fringe; the main area of her upper garment is white with blue and red vertical strips and has a patterned blue edge (Immerwahr 1990:95; Preziosi \& Hitchcock 1999:166,fig.104). Plain garments with yellow, blue, black and white edges are represented on a sarcophagus from Agia Triada in southern Crete (Figure 6). The loincloths of the male and female acrobats on the 'Taureador fresco' and the 'Cupbearer' from Knossos are orange-yellow with patterns. The limited colour palette of the wall paintings should not be taken too literally as the actual colour of the textiles, although a yellow dye, saffron, is recorded with textiles on a tablet from Knossos, (Rougemont 2007:46) and the early exploitation of the murex shell for purple dye may be related to the Minoan textile industry on Crete (Burke 2010,34-9, Burke 1999 cited in Militello 2007:42).

If the coloured, patterned clothing represented in the wall paintings was made of textiles then this can be equated with male and female clothing including sashes, loincloths, breechcloths, kilts, skirts, shawls, mantles, robes, capes, cloaks, tunics and short-sleeved bodies (Marcar 2005:40-1). The palace wall paintings adorn the residence of the elite of this hierarchy and the men and women in the wall paintings are often interpreted as high status individuals such as priests, goddesses or queens (Marinatos 2010:ch.3). For example, the blue knotted scarf of 'La Parisienne' from Knossos may identify her as a priestess (Immerwahr 1990:95). Other evidence for the high status of coloured cloth comes from the epigraphic sources; Near Eastern records record that purple dyed cloth was equally, if not more valuable than gold and silver (Wiener 1987 in Burke 2010,42). The patterned loincloths of the people from Keftiu in the Egyptian tombs of Rekhmire (Theban Tomb 100) and Menkheperraseneb (Theban Tomb 86) dated c.1450 BC, could have been made up of narrow, patterned, woven bands and panels sewn together (Barber 1991:336-7, Barber 1997:516-7, Davies 1933) (Figure 7). However, the location of Keftiu is debated. Although often accepted as originating from Crete, the people of Keftiu may have been from Cyprus or mainland Greece (Barber 1991:336-7). Indeed the confusion may relate to political events at this time, including the destructions on Crete, the beginning of Mycenaean participation in trade (summary Burke 2010:41) and Mycenaean influence on Minoan iconography at Knossos (Immerwahr 1990:78-83). There is also the question of the extent to which Minoan, Mycenaean and Theran costume styles influenced one another (Morgan 1988:118-20).

The problem of dealing with representations is that flat areas of colour could represent textiles or animal skins. The materials can only be distinguished if the artist draws attention to their material origin. Wrist straps on the arms of acrobats in the Taureador frescos at Knossos bring to mind the animal skin wrist straps or bracelets found in the Hallstatt salt mines, but the materials in the Knossos painting cannot be identified. The shoes or boots with patterns around the ankles in this and other wall paintings (Davies 1973:23,pl.XX; Immerwahr 1990:pl.41-42) may be leather and textiles, but again the evidence is inconclusive. Those artefacts and garments believed to be made from skins are recognized through surface decoration and shape. Through direct comparison with live animals in the paintings, the dappling on shields at Knossos can be identified as cattle skin. The seat of the folding stool and the front of one garment in the Campstool fresco from Knossos is textured like a fleece or fur (Immerwahr 1990:95,176; Preziosi \& Hitchcock:166,fig.105). The chariots on the Agia Triada sarcophagus are dappled like animal skins (Immerwahr 1990:pl. 52 \&53), which is in keeping with the knowledge of leather chariot construction from Egypt (Veldmeijer 2010,26). The "Captain of the Blacks" wears a hat that could be black goatskin (Immerwahr 1990:96). An infrequent, but interesting garment is the hide or fleecy skirt depicted on the Agia Triada sarcophagus and other media dating between LM I-III (Kontorli-Papadopoulou 
1996:91; Marcar 2005:35,40). The lower edge of these skirts is curved and pointed like the tail and flanks of a skin and the white surface is decorated with long, wavy tufts like sheep fleece (Immerwahr 1990:100-2) (Figure 6). A similar texture is seen on the full body garment on the figure at the head of the procession on the Agia Triada sarcophagus but the lower edge is not preserved. Interpretation of the iconography on suggests Crete such skirts were reserved for ritual, ceremonial occasions (Kontorli-Papadopoulou 1996:91) and possibly worn by a priestess or queen (Marinatos 2010,43). In the Egyptian tomb of Rekhmire two of the figures from Keftiu are wearing loincloths that show the markings and shape of feline skins (Davies 1973:23,pl.XX \& XIX), a garment not seen in the wall paintings on Crete. Other iconographic sources have been used to suggest lion pelts may have been foreign hunting trophies (Shapland 2010:285).

\section{Later $18^{\text {th }}$ Dynasty Egypt}

Egypt in the $18^{\text {th }}$ Dynasty was a hierarchal, bureaucratic state with the Pharaoh as its governor and divine leader; the power of kings and gods was epitomized through the massive scale of architecture, whether pyramids, temples or tombs (Kemp 1989:183-4). The cycle of the Nile was fundamental to the fertility of the soil which proved the sustenance for agriculture, horticulture and animal husbandry (Brewer 2007). People lived in houses made from dried mud bricks in villages and towns, varying according to status (Spence 2007:379). The $18^{\text {th }}$ Dynasty saw technological advances in the army and development of its administration (Spalinger 2007:123). Epigraphy and archaeological evidence show Egyptian influence at this time, whether through administrative control, warfare, alliance, trade or gift exchange, stretched from Nubia (south Egypt) through the Levant and Mesopotamia (Near East) and the eastern Mediterranean (Kendall 2007:411; Steel 2007:469-73; Bietak 2007:439-441; Wilkinson 2007:454-6).

The Egyptian evidence for preserved textiles and animal skins come from rock cut tombs and settlements where there are dry preservation conditions. Painted tomb scenes of wealthy, high status individuals show clothing and equipment use in everyday and ceremonial contexts. Dating in Egypt is based on the sequence of rulers documented in king lists that provide a relative chronology which is then calibrated against seasonal and astronomical events (Bierbrier 2006:41; Hornung, Krauss, \& Warburton 2006b; Hornung, Krauss, \& Warburton 2006c:47; Ryholt 2006). According to this scheme the fourteenth century BC falls into the second half of the eighteenth Dynasty of the New Kingdom and includes the reigns of Thutmose IV (1397-1388 BC), Akhenaten (1351-1334 BC) and Tutankhamun (1333-1319 BC) (Grajetzki \& Quirke 2000; Hornung, Krauss, \& Warburton 2006a ).

The majority of textiles in Egypt were linen (Hall 1986:9; Vogelsang-Eastwood 1992:1). Wool textiles in Egypt are rare, but not completely unknown. From the workman's' village of Amarna over $98 \%$ of the fibre specimens are linen and only $1 \%$ were wool; of these most are sheep's wool, but a few are from goat (Hall 1986,10, Kemp \& Vogelsang-Eastwood 2001:27-52). The vast majority of textiles were plain weave, with examples of basket weave (half basket weave, full basket weave, warp and weft faced full or half basket weave), repp and 'self-bands' added by weaving multiple threads in a single row of plain weave (Kemp \& Vogelsang-Eastwood 2001:95109; Roehrig 1996:95-107; Vogelsang-Eastwood 2000:274). Through variation in the thickness of threads and density of weave both sheer and coarse textiles were produced from the finest gauze to thick canvas like cloth (Donadoni Roveri 2001:21; Hall 1986:9; Kemp\& Vogelsang-Eastwood 2001:95; Vogelsang-Eastwood 1999:22) (Figure 8 \& 10). These sheer fabrics are represented in tomb paintings, for example the tunic worn by Nebamun is shown as semi-transparent and contrasts to the visually dense, white kilt (Figure 10). The tomb of Nebamun dates stylistically to the end of the reign of Amenhotep III (1390-1352 BC). From the workman's village at Amarna the majority of textiles fall between 5-40 threads per $\mathrm{cm}$ whereas the textiles from Tutankhamun's tomb range from 30 to 100 threads per cm (Vogelsang-Eastwood 1999:22, 100). This relates to written evidence which describes four grades of cloth, which can be translated as 'royal linen' 'fine thin cloth', 'thin 
cloth' and 'smooth or ordinary cloth' (Hall 1986,9). The coarse, ordinary cloth was the most common, cheapest type, but this was also suitable for warm, evening clothing (Hall 1986:9).

Simple and elaborate fringes are preserved on textiles in tomb paintings and engraved on statues (Donadoni Roveri 2001:21-22,Roehrig 1996:22). Although not common, there are examples of pile textiles either added during the weaving or stitched on afterwards (Kemp \& Vogelsang-Eastwood 2001:149-52, Roehrig 1996:22-4). An example of linen bedding with knotted pile was placed in the rich and well preserved tomb of the architect Kha and his wife Merit at Deir el Medina (Theban Tomb 8) (Hall 1986:38-9, Roehrig 1996:24) and fragments of pile textiles have been excavated from the workman's' village at Amarna (Kemp \& Vogelsang-Eastwood 2001:147-). Pleated linen cloth is known from extant garments, wall paintings and statues of men and women; as well as the visual appeal, excess pleated fabric may have provided extra warmth (Hall 1986,22,29,32,52, Vogelsang-Eastwood 2000:281).

The majority of preserved linen (and wool) textiles are shades of white, linen ranged from white through light brown to golden brown (Hall 1986:9). Bright white linen would have to be obtained by bleaching; a technique that is attested by a linen list from the tomb of Rekhmire (VogelsangEastwood 2000:280). Patterned textiles may well have been confined to use by the royal household or high officials; labourers clothing was plain (Hall 1986:23-6; Vogelsang-Eastwood 2000:275). Textile colours include red, blue, yellow, green, purple, brown and black (Germer 1992:20-70; Hall 1986:10-1). Examples of the labour-intensive tapestry weave and coloured, patterned repp bands are known from rich tombs including those of Kha and Merit (Figure 8), Thutmose IV and Tutankhamun, where these techniques were used to decorate tunics, mats, belts, arrow quivers, bedding and cushions (Donadoni Roveri 2001:22; Vogelsang-Eastwood 2000:275). In these and other rich tombs embroidery, painting, appliqué, the application of beads and small gold platelets are known (Hall 1986:43; Vogelsang-Eastwood 2000:275-6). Warp-faced braids decorated the edges of high quality textiles (Vogelsang-Eastwood 2000:276) and patterned, painted tomb ceilings may represent elaborate textile drapes (Barber 1991:340). Although the quality varied, linen textile was used for clothing by men and women, commoner and elite alike (Hall 1986:9,62-4). In this period typically, men wore triangular loincloths, bag-tunics ${ }^{2}$, wrap-around kilts of various lengths sometime layered one over another, triangular aprons, sashes, straps and cloaks of in a variety of styles (Vogelsang-Eastwood 1993:180). Women wore linen loincloths, bag-tunics, skirts of various lengths, wrap around dresses both in a simple and more complex knotted style, sashes, straps, wrap around shawls and long cloaks (Vogelsang-Eastwood 1993:180). Textiles for domestic use include bedding sheets and covers, cushions, towels, table and jar covers, bags, lamp wicks, bandages, awnings and mats (Vogelsang-Eastwood 2000:291-3,Donadoni Roveri 2001, Hall 1986:38). They played a special role in religious ceremonies; as abundant mummy wrappings, shrouds, to cover shrine statues and as sacred cloth offered to the gods (Hall 1986:18,Vogelsang-Eastwood 2000:2934).

Cow, goat and gazelle skins were common, with exotic skins including leopard and cheetah (DrielMurray 2000:302). Skins were both hairy and depilated. Alongside the naturally coloured and patterned skins, some were brightly coloured often in red and green; decadent artefacts are intricately decorated with bright floral or linear patterns in raised relief, open work, couching and appliqué (Driel-Murray 2000:306, 311; Veldmeijer \& Endenburg 2007; Veldmeijer 2010:22-24). Animal skins such as goat were commonly used for shoes and sandals, tool lashings, bags and goatskins water containers (Veldmeijer 2010:29). Animal skin products served a special role in armoury including as arrow quivers, shields, and arm guards (Driel-Murray 2000:310; Veldmeijer 2010:26-8). Scale leather armour lined with linen is known from Tutankhamun's tomb (VogelsangEastwood 1999:109-10). Chariots, such as that from Thutmosis IV's tomb were lashed with and sheathed in rawhide (Veldmeijer 2010:26-8). Stool seats depicted in wealthy tombs were made from skins or laced thong, as seen in a cow skin example painted in the tomb of Huy (Theban Tomb 40) 
(Davies \& Gardiner 1926:pl. XXIV; Driel-Murray 2000:312) and the tomb of Nebamun (Theban Tomb 63) (Figure 10). In Tutankhamun's tomb an ivory seat was inlaid to appear like cheetah and dappled skins (Carter 1933:111-113,pl. XXXIII). Tomb paintings includes gifts of rectangular shields of leopard and cheetah skins (Davies \& Gardiner 1926:pl.XVI,XXIV,CVII).

Skins were not commonly used for clothing in Egypt with the exception of loincloths worn by men, including those simply cut from skins with or without hair and others with punched holes or numerous small slits (Driel-Murray 2000:302,311; Vogelsang-Eastwood 1993:17-31). A fine mesh leather loincloth is known from the tomb of Maiherpri, an official of part Nubian origin, dating to the reign of Thutmosis IV, slit work examples are known from Amarna (Veldmeijer 2010:29; Vogelsang-Eastwood 1993:18) (Figure 9). Such loincloths may have originated from Nubia in the south of Egypt where skin clothing for men and women was common (Hall 1986,34-5;VogelsangEastwood 1993:20). Many tomb paintings show priests wearing leopard skin drapes. Two such garments were found in Tutankhamun's tomb; one an actual leopard skin decorated with the king's cartouches, the other a textile version shaped and embroidered to resemble a leopard skin complete with wooden head (Driel-Murray 2000:302; Vogelsang-Eastwood 1999:27,105-6.fig.6:11).

\section{Comparing cloth cultures}

The results above describe the evidence for cloth cultures from four areas according to the categories outlined in the method: raw materials, the fabric structure and thread count (textiles only), decoration and finish, use and context. These are summarized in Table 2. The categories bring together materials and use, and the evidence for textiles and animal skins is brought together across all areas.

Some of the general problems of research into organic materials were outlined in the method section, more specifically there are problems with the evidence used here. Clearly, the sample size is varied. The Hallstatt salt mines are the most geographically limited sample and Final Palace period Crete provide the least preserved remains, which contrasts to the quantity and geographical scope of the evidence from Egypt and Scandinavia. There are differences in context and deposition. The southern Scandinavian burials, the wall paintings of Crete and the Egyptian tombs are all contexts of high status individuals participating in elite display of one kind or another and contrast to the working environment of the Hallstatt salt mines or Amarna workshops of Egypt. This no doubt affected the deposition of materials and interpretation. Significantly, the evidence cited above includes epigraphic and iconographic sources which are processed in different ways from other line of evidence and the source critical approaches of scholars working on these fields vary. The same can be said of the theoretical and methodological perspective of scholars working in different regions and the problem of comparisons between societies with very different social organisation. What then can we understand of these results from a comparative perspective? This discussion address concepts of technological choices and style in cloth cultures, through aspects such as availability, climate, material properties, ideology, status, wealth and value.

\section{Raw materials and economy}

The main raw materials used for textiles and skins were obtained from the farming economy and show both widespread use and regional distinctions. Sheep's wool was used as a fibre for textiles in all four areas, but was proportionally more important in the southern Scandinavian burials, the Hallstatt salt mines and as a fibre resources in the Knossos archive; wool is rare in the settlements and burials of Egypt. Linen is proportionally more important in Egypt, present on Final Palace period Crete and the Hallstatt salt mines but absent in the southern Scandinavian burials. Textile fibre distributions have been noted elsewhere (Barber 1991:ch.1; Bender Jørgensen 1992:116-20). Nettle fibre has only been identified once on Crete along with goat hair which is also known from Egypt. The majority of skins in all areas are from domestic animals including sheep, cow and goat. Skins from wild species were used and appear to vary according to the regional fauna; otter in 
southern Scandinavia, possibly chamois, ibex and other fur-bearing species from the Hallstatt salt mines (although noting this includes Iron Age data), gazelle, leopard and cheetah in Egypt. The domestic species (flax, sheep, goat, cattle) are all based in Neolithic agriculture and were well established resources in much of Europe, the Near East and Mediterranean. Only in Denmark does flax cultivation seem to be absent at this time (Henriksen 2009). The exploitation of wool as a later technological development the so-called 'Secondary Products Revolution' which occurred well before the period studied here (Sherratt 1981:159,180-1).

As the raw materials for cloth were mainly obtained from domestic species of plant and animal, their availability depended on the farming economy and use of the landscape. Animal skins are only obtained after the animal has been killed (primary product), whereas sheep (secondary product) or flax fibres can be harvested year after year. There was a continuous demand for textiles and animal skins. How this may have affected the quantity available or who they were available to remains unclear. In Egypt cattle were expensive to maintain, so it is possible that the products of cattle were restricted to the upper classes (Brewer 2007:142). Brewer identifies these products as meat and milk, but as a primary product skins may be included. Egyptian tomb paintings of the $18^{\text {th }}$ Dynasty show men and women harvesting tall stems of flax (Vogelsang-Eastwood 1992:44) showing the importance of this crop in an abundant afterlife. This may have been quite different for farming or pastoral societies in Europe where availability would depend on the frequency with which animals were slaughtered and may also related to the status attached to herds. The cow skin shrouds of southern Scandinavia have been interpreted as the remains of funeral feast (Glob 1974:40). If this were the case, maybe the slaughter of a cow or bull was a luxury reserved for funeral festivities in a society where wool fibres (secondary products) are the main form of preserved cloth. This does not preclude trade as a source of raw materials. The Knossos archives demonstrate the great importance of flock management and textile production for the palace economy (Preston 2008:313; Wardle 1994:227) and at least some of these textiles were for export and are among the goods offered by the Keftiu in the tomb of Menkheperraseneb (Figure 7). Written sources such as the Amarna letters document the exchange of fine textiles (Knapp 1991 in Burke 2010:40-1). As noted above, the wild species of skins relate to fauna within the regional vicinity and were possibly a welcome supplementary resource of skins, they may also have been a luxury associated with hunting. Textiles, feline skins and cattle hides were offered as tribute in a number of the tomb scenes of Egypt, showing their value as commodities (for example Davies \& Gardiner 1926:pl.XVI,XXIV, CVII). It seems highly likely that textiles and skins were have been features of trade or exchange in Europe although difficult to prove (suggestions in Sherratt 1993:31,36-7). Evidence for the circulation of textile fibres may be aided by future development of isotope analysis of wool (Frei et al. 2009). Therefore raw materials were widespread, but with regional distinctions.

\section{Clothing and climate}

One of the reasons for the regional distribution of raw material preferences could be climate. At this time central Europe had a temperate Continental climate of cold winters and warm summers with precipitation throughout the year (Szeverenyi 2004). Like today, this contrasted to Egypt with its hot, dry climatic conditions and dependence on the Nile for water (Moeller 2007:58). In Central and Northern Europe it can be argued that wool for textiles provided the warm, insulating material that could have replaced leather and fur for clothing, a substitution that could not have occurred in the Neolithic with its reliance on plant fibres such as linen or tree bast (Rast-Eicher 2005:124). Similarly it is not surprising that Egyptians appreciated the cool feel of linen textiles and their ability to shed dirt and dust (Barber 1991:15). On the basis of certain material properties this seems highly plausible: flax fibres are cool, crisp and smooth to the touch, while sheep's wool feels warm to the touch and has excellent insulating properties (Harris 2010:105). Similarly, animal skins with dense, fine underwool can be warm and insulating, as this is one of the ways some animals (such as otter) protect themselves from the cold (Kruuk 1995:184-20). 
However, all areas experienced seasonal variation in climate and temperature change between the chill of night and heat of the day. These differences were not necessarily accommodated by change raw material used for clothing. The shape of garments and cloth type are equally important. For example in southern Scandinavia wool textiles were used to produce heavy, warm clothing (cloaks, skirts, caps) and blankets but also lightweight clothing (corded skirts, blouses). In Egypt thick and heavy linen textiles are interpreted as adaptations for warm clothing, for example Kha's heavy linen 'winter tunic' (Figure 8) and pile bedding from the same tomb (see above); ample pleated linen clothing may have been another way to keep warm (Hall 1986:32). Not all animal species rely on fur for insulation, some rely on blubber (Kruuk 1995:184-20) and do not have a well developed underwool and therefore, the animal skin product would not be insulating. While there is a general assumption in Europe that one of the prime reasons for skin clothing was for its warmth, this correlation is contradicted by the importance of skin clothing and leatherworking tradition in Nubia, southern Egypt (Driel-Murray 2000:300; Veldmeijer 2010:28). At 20-24 latitude, this is one of the hottest places on the planet. Here and in Egypt leather loincloths were aerated through cut work and slit work. This shows that the local needs were met through skill and versatility in the manipulation of cloth resources.

\section{Material choices}

Fibres, skins and cloth types have multiple properties that would have been important in different situations. Flax has a high tensile strength and resists abrasion (good for sails and sacks), wool is elastic and burns very slowly (good for clothing and pyrotechnic activities) (Harris 2010:106-7). The useful properties of animal skins do not only reside in the hair or fur, but also the skin and aspects such as the size, thickness and resilience vary according to species, age and area of the skin (Kellogg 1984:37,108). The thickness, strength and durability of mature cattle skin, for example, was universally appreciated. It was used for shields, quivers and sandals in Egypt (Driel-Murray 2000:302), as carry sacks in Hallstatt (Barth 1992) and possibly shields and chariots on Crete (Immerwahr 1990:pl.49,52,53).

Choices in materials are not only made by properties but also cultural beliefs and some of the evidence suggests this was the case in these examples. Animal skins with their hair on are visual keys to the species they originate from, an aspect unlikely to have been lost on the agrarian communities of the Bronze Age. Therefore, the shields and chariot at Knossos may have been made from cattle skin due to its strength and resistance, but this visual reference should not be separated from beliefs attached to the bull on Crete and indeed throughout the Near East and Egypt (Marinatos 2010:ch.9). A similar argument could be made for cheetahs and leopards skins in Egypt. The low quantity of wool textiles in Egypt may be explained by claims in later written sources that Egyptians considered wool unclean, therefore unsuitable for burials. However, the validity of sources should be treated with caution for this early period (Vogelsang-Eastwood 2000:269). This contrasts with the dominance of wool in the burials of southern Scandinavia, showing diametrically opposed practice. Hans van Wees suggests it is only in the sixth century BC in Greece that fleeces and goatskins became signs of rusticity and poverty, whereas in the earlier written sources of Homer and Hesiod, these materials did not carry such connotations (Wees 2005:48-9). Colour adds another layer of potential symbolism that was probably important everywhere but difficult to prove. In Egyptian iconography, for example, white was associated with purity and the notion of light, black with the underworld, fertility and regeneration, turquoise or lapis lazuli with the dark sky and rebirth of the sun (Robins 2007,362).

Local choices in materials may lead to regionally distinct cloth traditions and in turn create identities associated with places or people. The notion of ethnicity or 'other' is presented in Egyptian wall painting, and costume along with skin colour, nose shape and hairstyle to portray Nubians, Egyptians, Libyans, Asiatics and Keftiu (Davies 1973:23;Tyson-Smith 2007:220). While their costumes are distinguished through garment shape and style, they are also distinguished by 
decorative types and raw materials. These stereotypes are artistic devices and should not be taken completely literally, sometimes the painters seem to have confused these visual clues as if working from copybooks (Keeper and Staff of the Dept. of Ancient Egypt and Sudan 2007:251). However, other evidence suggests at least a superficial accuracy, the multi-coloured and intricately patterned loincloths of the men from Keftiu from the tomb of Menkheperraseneb and Rekhmire (Davies 1973:22-3,pl. XIX-XXI,XXIX,) find a rough equivalent in the pattered loincloths of the 'Taureador fresoes' and 'Cupbearer' from Knossos. In the tomb of Rekhmire and elsewhere Nubians are shown in dappled or pierced animal skin loincloths (Davies 1973:26-7) which may be associated with the leatherworking tradition of Nubia. It seems highly likely that such distinctions were also evidence in north and central Europe. For example, the early presence of twill in the Hallstatt salt mines (Grömer 2009:108), northern Italy and Switzerland (see above) may indicate a regional speciality in these diagonally textured textiles, but the evidence is too scarce to prove this point.

\section{Textile traditions}

In terms of size, whole preserved textiles show that weavers of the Bronze Age were able to produce large and small textiles. Fringes were used in all areas. The well preserved textiles of southern Scandinavia and Egypt demonstrate that textiles of well over $2 \mathrm{~m}$ could be woven, as well as narrow bands, sashes and belts (Broholm \& Hald 1940:22,82; Hall 1986:24-6; Kemp \& Vogelsang-Eastwood 2001:440,fig.11.2).

Plain weave and repp are the most common fabric structures and are found in all areas with a reasonable body of preserved textiles. With its long antiquity, plain weave is the simplest, plainest weave. It is also extremely versatile in terms of material properties and appearance (Chandler 1995:ch.6). Variety in plain weave is found everywhere. Textiles of the same fabric structure may look quite different and have different material properties. Quality in terms of fineness and coarseness is measured in part by thread count. As a rule of thumb, the higher the thread count, the finer the cloth. For example, a plain weave textile with five threads per $\mathrm{cm}$ is likely to have thicker threads and to be coarser than a textile with 30 threads per $\mathrm{cm}$. For example, in the Hallstatt salt mines the most common textiles have a thread diameters of $1-1.5 \mathrm{~mm}$ and a thread count of 5-10 per $\mathrm{cm}$, of these the examples with the thickest threads $(1.5-2 \mathrm{~mm})$ and lowest thread count $(5$ per $\mathrm{cm})$ are coarse and interpreted as possible hauling sacks (Grömer 2005:20;2010:120,abb.550). However, there are finer textiles from the mines with thread diameters of $0.3-0.4 \mathrm{~mm}$ to $0.6-0.9 \mathrm{~mm}$ and thread counts between 6-10 per cm (Grömer 2005:28-29,fig 14.). Thread count is a rough indicator of quality, but fabric density or visual thickness varies according to the density of the cloth and diameter of warp and weft (Hammarlund 2004:8-9). Based on this visual thickness classification, Hallstatt textiles can be grouped according to whether they are visually dense or open (Grömer 2007:90-1). The linen textiles of Egypt have the widest range of thread counts from the low thread count coarse cloth from with up to 100 threads per $\mathrm{cm}$ in royal tombs (Vogelsang-Eastwood 1999:22,100). There is also variation in visual thickness between dense and open. Fine, open textiles produced sheer or transparent textiles, as for example the shawls occasionally worn by men in the New Kingdom (Hall 1986:21).

Technically in terms of the fabric structures, repp, basket weave and tapestry weave are simple variations of plain weave where the weft passes under and over each warp, alternating in subsequent rows, although in basket weave the threads are doubled (Chandler 1995:120-1;Emery 1966, 75-90). Weaving with supplementary threads to create patterns and pile are described as compound weaves (Emery 1966:140-9), but are technically still fairly simple variations of plain weave. Twill weaves are float weaves where warp or weft passes over two or more units of the opposite element; twills are characterized by their diagonal patterns (Emery 1966:75,92-107). Repp has a slight ribbed appearance, twill textiles are characterized by subtle diagonal lines, and basket weave is distinct from plain weave due to its double threads (Chandler 1995:120-9) (Table 1). While each study area showed innovation in the basic plain weave, these innovations were different. In southern 
Scandinavia, repp with extended fringe was used for the corded skirts. Twill is known from the Hallstatt salt mines but could be argued that it may be represented in diagonal patterns of some of the textiles from the late Minoan palaces. Tapestry weave is so far found only in Egypt but the patterns on the wall paintings of the Final Palace period suggest it was practised here too, possibly along with weaving with supplementary warps of wefts to create coloured patterns. Pile was added to wool textiles in southern Scandinavia and for linen in Egypt, although the former are stitched on afterwards and the latter added in the weave. Different fabric structures provided visual distinctions between textiles in the same cloth cultures and for this reason have potential as visual markers of social role and status.

Colour, texture, pattern, decoration and qualities such as fineness and coarseness demonstrate the visual value judgements and cultural choices inherent in technological styles (Lecthman 1975:14-5; Jopling 1975:219-20). These cloth styles may form an aspect of social identities. As a repository for precious raw materials, dyes and human labour (textiles: Schneider \& Weiner 1986:2), cloth may be used to convey status and social position. In Egypt, the labour intensive and colourful tapestry weave textiles are only found in the royal or wealthy tombs (Vogelsang-Eastwood 2000:275). Spinning is an incredibly time consuming process so textiles with a high thread count (more threads per centimetre) are substantially more time consuming to produce than textiles with a low thread count because they consume more thread (Andersson and Nosch 2003:198-9). As well as the ubiquitous low thread count textiles found in all areas of this study (from 5 per cm), Egypt has preserved textiles with very high thread counts (up to 100 per $\mathrm{cm}$ ). In Egypt, textiles with high thread counts are associated with wealth and status, and found in wealthy burials such as Tutankhamun's tomb (Vogelsang-Eastwood 1999:22, 100). This may be in part due to with fineness, but also the centralized, hierarchal structure of Egyptian society allowing the patronage and production of such time consuming cloth. By contrast, the southern Scandinavian with an average of 3-6 threads per cm (Bender Jørgensen 1986:289-92) and the Hallstatt textiles with only a few examples above 15 threads per centimetre show a much narrower range (Grömer 2010:120, Abb.55). It may be that the weavers producing textiles in these areas lacked the skills, knowledge or centralized production to weave these very fine textiles. However, the fineness and coarseness of cloth is relative and the absence of high thread count textiles need not be seen as the absence textiles perceived as high quality. On the basis of elaborate metal grave goods, the low thread count textiles of southern Scandinavia are clearly suitable for the burial of wealthy individuals in this context.

\section{Animal skin traditions}

The status attached to textiles has led to an assumption that in the Bronze Age animal skins were either of lower status or used in a purely utilitarian fashion. Of the evidence presented here, the burials of southern Scandinavia, the palace wall paintings of Final Palace period Crete and Egyptian tomb contents and tomb paintings are arenas where men and women presented their wealth and status through material goods, such as metal weapons, drinking cups, gold and bronze jewellery and folding stools. Both textiles and animal skins are found in these contexts, demonstrating how both were part of the material status trappings of the wealthy or high status men and women although they were used in different ways.

In clothing, for example, the men and women in the southern Scandinavian burials wore textiles for large and small garments (blouse, skirt, wrap-around, kilt, cloak, cap, socks) and blankets while animal skins were used for small garments and artefacts (stool seats, straps, shoes, knife covers, lining for sword sheaths) with the exception of the large cow skin wraps. In the Final Palace period on Crete, textiles appear to be the main material used for men and women's clothing, although there the rare hide or fleecy skirts were possibly reserved for ritual and ceremonial use (Sakellaraki in Kontorili-Papdopoulou 1996:91). In Egypt textiles were the main cloth for clothing wealthy men and women as the evidence from the Theban and royal tombs testify and there is sufficient evidence 
to demonstrate that textiles were worn by men, women and children from all echelons of society but that the quality varied (Hall 1986:ch.4). In Egypt, animal skins were not common as clothing although there are several exception: the leather loincloths worn by men particularly sailors, soldiers, craftsmen and servants but was also found in tombs of high officials and pharaohs (Vogelsang-Eastwood 1993:17-31), the Nubian tradition of skin clothing and the leopard skin drapes worn as badge of priestly office (see above). However, animal skins were used by high status individuals whether as chariot trappings, bow cases, quivers and shoes, they and were sometimes elaborately coloured and decorated (Driel-Murray 2000:306,311; Veldmeijer 2010:26). When Carter opened Tutankhamun's tomb he commented that there must have been considerable amounts of leather in the tomb as horse trappings, seats for stools and sandals but that most of it has turned into a brittle, pitch like mass (Carter 1927:175-6). On a broad scale, the evidence suggests that while textiles seem to have been the preferred cloth for clothing for high status individuals, certain forms of clothing made from animal skins also fulfilled this role. Here, the species or context may have been important. The problem with much of this evidence is that there is not enough evidence of non-elite clothing. The Hallstatt salt mines and Egyptian evidence are most appropriate here, and again, both show the possibility that both textiles and animal skin clothing had their place, although in Egypt the preference is clearly for textile clothing.

There is a wall painting of the late fourteenth or thirteenth century BC (LHIIIB) on mainland Greece, which hints at a possible negative attitude towards animal skin clothing. At the palace of Nestor, Pylos a warfare scene shows combatants are duelling with daggers. Warriors in combat are shown in distinct clothing: the Mycenaean's wear boar's-tooth helmet, baldric, and short white skirt over laid with long blank triangles and white greaves. The skirt, greaves and baldric may well have been made of leather or sheet metal, although the artist gives no clues (Lang 1969:71). Their opponents are bare legged, shoeless and wear ragged garments tied around the neck with black hair makings which Mabel Lang identified as animal skin, possibly sheepskin (Lang 1969:71,227). She and later Jack Davis and John Bennet have argued that although we can take the scene at face value showing well clothed Mycenaean's fighting their bare-foot, skin clad enemies, it may also be a device to differentiate them from the 'other' (Davis \& Bennet 1999; Lang 1969:22). As greaves, baldric and skirt could be leather, it is possibly the hairy appearance and tailoring of the enemy's skin garments differentiates them rather than the animal skin content. Looking at another example, the Hallstatt salt mines show that hairy or furry animal skin were common in the mines. But was it desirable? The conical hat, two wrist straps (bracelets) and a finger bandage have the hair side facing inwards and the flesh side facing out (Harris: study visit 2009). Was this because it was better to wear the hair side against the skin, or because it was better to show the smooth flesh side? Other whole artefacts in the mine such as the cow skin carry sacks have the hair side facing outwards (Barth 1992). On a broad geographical scale, the association of textiles with elite clothing is strong but the contrary argument that animal skins were associated with low status clothing or were low status materials is not supported by the evidence in this paper. Indeed, the evidence suggests there were different attitudes to animal skin clothing in the Bronze Age which need to be addressed at a regional or local level.

Even if they were not especially prized as clothing materials, animal skins were an important raw material and are found in both working environments such as the salt mines and as high quality goods in contexts such as the royal tomb of Tutankhamun. In the working environment of the Hallstatt salt mines, animal skins with the hair left on are common (Harris 2006:71-2). As bags, construction materials, bandages and wrist straps this support the argument that animal skins were preferred as hard wearing, working materials. However, this is potentially biased by preservation factors as there is little direct evidence of animal skin use outside the mines. This contrasts with the Egyptian material where elaborate, decorative examples of animal skin products are known for shoes, weaponry and chariots (Driel-Murray 2000:306,311; Veldmeijer 2010:22-24). Evidence for decorated animal skins is rare outside Egypt, although they would be difficult to differentiate from 
textiles in the wall paintings on Crete. The single decorated example from the Hallstatt salt mine is insufficient to prove a wider tradition. However, as the research field grows and more finds are investigated this will be an interesting area to follow.

\section{Conclusion}

Fragile organic materials such as textiles and animal skins provide a number of problems for the archaeologist. Primarily their poor preservation contrasts to their economic, social and visual importance in the past. There is therefore a need to approach these materials using methodological devices to open up new ways of thinking and allow alternative interpretations of these materials in the past. Through a wide ranging comparative approach, this study has brought together evidence for textiles and animal skins as the material components of cloth cultures from north Europe to Egypt focusing on a short period of time in the Bronze Age. Its scope has necessitated the selection of principle points and categories of analysis with the intention to present a balanced view in the comparison of cloth cultures despite the diversity of preservation contexts, the unequal quantity of data and contrasting deposition contexts.

From this study, it is possible to recognize that there are some universally shared technological and socially defined cloth culture principles. All the cloth cultures investigated here are based on woven textiles and animal skins from largely domestic resources, from the oak coffin burials of southern Scandinavia, the Hallstatt salt mines of Austria, Final Palace period Crete to later $18^{\text {th }}$ Dynasty Egypt. Although this may seem obvious, cloth cultures vary across time and space; the Pacific and Indonesian cloth cultures cited in the introduction (Hauser-Schäblin 1996) are based in profoundly different technologies. These widespread similarities have their roots in the interconnected Bronze Age world. The social organisation of each of these four studies varied, but the desire to produce elaborate, varied types of cloth is found in all of them although how this is achieved varies. For example tapestry weave is not known in central and north Europe, although colour is widely appreciated. Both textiles and animal skins were used to produce large and small artefacts of many kinds. Our knowledge of these is often limited by the fragmentary nature of finds, but this comparative method of data collection demonstrates the potential of animal skin in all aspects of life including working environments, burials, elite regalia, bandages, weaponry and transport. Textiles were similarly versatile as bags, bandages, bedding, sails or drapes and were the most commonly used material for clothing, but animal skins were regularly used in this role although the purpose of this clothing varies in each body of evidence. Where there is comparable evidence it is possible to see that values attached to materials varied regionally, for example the type of textiles fibres found in burials. There was great versatility and creativity in the use of materials, thick linens were woven for warmer clothing, wool and animal skins were adapted for lightweight cloth.

Although some of the results may have been readily anticipated, such as regional diversity in textile types the comparative approach demonstrates some of the actual distinctions that are known from the current state of evidence. This study looked at four areas with good sources of evidence. By doing this, it has only touched on a fraction of the local, regional studies of textiles and animal skins of the Bronze Age. Further studies will hopefully bring out the rich diversity of cloth cultures at this time and draw attention to the way these materials were part of the social life of the people of the Bronze Age.

\section{Acknowledgements}

I am grateful to the British Academy and Institute of Archaeology, UCL for the opportunity to pursue this research as Post-doctoral Fellow and the Aylwyn Cotton Foundation for their financial support in the form of an Independent Fellowship. Many people helped to navigate the vast realms of evidence and literature, listed alphabetically: Cyprian Broodbank, Jo Cutler, Rosalind Janssen, Janet Johnstone, Kathryn Piquette, Jo Rowlands, Bill Sillar and Andrew Shapland. I am grateful for the museum staff who granted me permission to study their artefacts and discussed their collections: 
Benoît Mater-Koopstra, Drents Museum; Poul Otto Nielsen, Susanne Klingenberg \& Irene Skals, National Museum of Denmark; Jørgen A. Jacobsen, Odense Bys Museer; Anton Kern, Hans Reschrieter and Karina Grömer, Helga Rösel-Mautendorfer Natural History Museum, Vienna; Stephen Quirke, Petrie Museum, UCL; Department of Ancient Egypt and Sudan, The British Museum. With heartfelt thanks to three anonymous reviewers, Hannah Cordts, Margarita Gleba, Sue Hamilton, Mark Pearce, Philippa White and Ruth Whitehouse for their encouragement and useful comments on earlier drafts of this paper.

\section{References}

ALLGROVE-MCDOWELL, J., 2003 Industries of the Near East and Europe in Prehistory. In, D. Jenkins (eds) The Cambridge History of Western Textiles, Cambridge, Cambridge University Press: 30-9

ANDERSSON, E. \& M.-L. B. NOSCH, 2003. With a little help from my friends: investigating Mycenaean textiles with help from Scandinavian experimental archaeology. In K. P. Foster \& R. Laffineur (Eds.) Metron. Measuring the Aegean Bronze Age. Proceedings of the 9th International Aegean Conference/9e Rencontre égéenne internationale New Haven, Yale University, 18-21 April 2002., vol. 24 , Université de Liège, Histoire de l'art et archéologie de la Grèce antique. University of Texas at Austin Program in Aegean Scripts and Prehistory:192-206.

ANDERSSON STRAND, E., M. GLEBA, U. MANNERING, M.L-B. NOSCH, \& I. SKALS, 2010 Old Textiles - New Possibilities. European Journal of Archaeology, August,13: 149-173

ANER, E. \& K. KERSTEIN, 1973ff. Die Funde der älteren Bronzezeit des nordischen Kreises in Dänemark, Schleswig-Holstein und Niedersachsen. Band 1ff.. Frederiksborg und København Amt Verlag Nationalmuseum København Karl Wachholtz Verlag Neumünster, København.

BARBER, E. J. W., 1991. Prehistoric Textiles; the development of Cloth in the Neolithic and Bronze Age with special reference to the Aegean. Princeton University Press, Princeton, New Jersey.

BARBER, E. J. W., 1997. Minoan women and the challenges of weaving for home, trade and shrine. In International Aegean Conference (6th : 1996 : Philadelphia, Pa.): Techne : craftsmen, craftswomen and craftsmanship in the Aegean Bronze Age : proceedings of the 6th International Aegean Conference/6e Rencontre égéenne internationale Philadelphia, Temple University, 18-21 April 1996. 16. edn, R. Laffineur \& P. P. Betancourt, eds., Université de Liège, Liège BARNES, R. \& J. B. EICHER, 1993, Introduction. In R. Barnes \& J. B. Eicher (Eds.) Dress and Gender: Making and Meaning in Cultural Contexts, vol. 2, Oxford, Berg Providence:1-7 BARTH, F. E., 1992, Zu den Tragsäcken aus dem Salzbergwerk Hallstatt., Archaeologia Austriaca, vol. 76:121-127.

BARTH, F. E., 1994. Ein Füllort des 12.Jahrhunderts v. Chr.im Hallstätter Salzberg. Mitteilungen der Anthropologischen Gesellschaft in Wien, 123/124:27-38.

BENDER JØRGENSEN, L., 1986. Forhistoriske textiler i Skandinavien : Prehistoric Scandinavian textiles. Kongelige Nordiske Oldskriftselskab, København.

BENDER JØRGENSEN, L., 1992. North European textiles until AD 1000. Aarhus University Press, Aarhus.

BENDER JØRGENSEN, L., 2003. Europe. . IN, D. Jenkins (eds) The Cambridge History of Western Textiles, Cambridge, Cambridge University Press.

BENDER JØRGENSEN, L., E. MUNKSGAARD, \& K.-H. STÆRMOSE NEILSEN, 1982.

Melhøj-fundet. En hidtil upåagtet parallel til Skrydstrup-fundet / English Summary: Melhøj - an Unheeded Parallel to the Skrydstrup Find. Aarbøger for Nordisk Oldkyndighed og Historie: 19-75. BERGERBRANT, S., 2007. Bronze Age Identities: Costume, Conflict and Contact in Northern Europe 1600-1300 BC. Bricoleur Press, Lindome.

BIERBRIER, M. L., 2006. Genealogy and Chronology. In Ancient Egyptian chronology, E. Hornung, R. Krauss, \& D. A. Warburton, eds., Brill, Leiden: 37-44. 
BIETAK, M., 2007, Egypt and the Levant, In T. Wilkinson (Ed.) The Egyptian world, London, Routledge: 417-448.

BOYE, V., 1986/1896. Fund af egekister fra bronzealderen i Danmark. Illustreret af A.P. Madsen. Med efterskrift af Mogens Ørsnes. Reprinted by the publishers, Wormianum, Aarhus.

BREWER, D., 2007. Agriculture and Animal Husbandry. In T. Wilkinson (Ed.) The Egyptian world. London, Routledge: 131-145.

BROHOLM, H. C. \& M. HALD, 1940. Costumes of the Bronze Age in Denmark: Contributions to the Archaeology and Textile history of the Bronze Age. NYT Nordisk Forlag. Arnold Busck, Copenhagen.

BROODBANK, C. (2009) The Mediterranean and its Hinterland. In B. Cunliffe, C. Gosden, \& R. A. Joyce (Eds.) The Oxford handbook of archaeology. Oxford, Oxford University Press:720.

BURKE, B., 2010, From Minos to Midas : ancient cloth production in the Aegean and in Anatolia. Ancient textiles series, vol.7., Oxford \& Oakville, Oxbow Books

BURNHAM, D. K. (1973) Cut My Cote.Toronto, The Royal Ontario Museum.

CARTER, H., 1927. The tomb of Tut-Ankh-Amen discovered by the late Earl of Carnarvon and Howard Carter. Vol.2. Cassell, London.

CARTER, H., 1933. The tomb of Tut-Ankh-Amen discovered by the late Earl of Carnarvon and Howard Carter. Vol.3. Cassell, London.

CHANDLER, D., 1995. Learning to Weave. Colorado, Interweave Press.

CHRISTENSEN, K., 2006. Dendrochronology Dating of Bronze Age Oak Coffins from Denmark \& Schleswig, Acta Archaeologica, vol. 77: 163-242.

COMIS, S. Y., 2003. Aktuelles aus den Nachbarländern. In Textilien aus Archäologie und

Geschichte. Festschrift für Klaus Tidow. L. Bender Jørgensen, J. Banck-Burgess, \& A. Rast-Eicher, eds., Wachholtz, Neumünster: 193-204.

DAVIES, N. M. \& A. H. GARDINER, 1926. The tomb of Huy, Viceroy of Nubia in the reign of Tut'ankhamun, (no. 40) copied in line and colour by Nina de Garis Davies and with explanatory text by Alan H. Gardiner. Egypt Exploration Society, London.

DAVIES, N.M. 1933, The tombs of Menkheperrasonb, Amenmosĕ, and another (nos.86,112,42,226) with plates by Nina de Garis Davies and with an explanatory text by Norman de Garis Davies. The Egypt Exploration Society, London.

DAVIES, N. d. G. 1973, The tomb of Rekh-mi-Re at Thebes. Arno Press, New York.

DAVIS, J. L. \& J. BENNET, 1999. Making Mycenaean's: Warfare, Territorial Expansion, and

Representations of the Other in the Pylian Kingdom, In POLEMOS. Le contexte guerrier en Égée à l'Âge du Bronze. vol. 19 R. Laffineur, ed., Aegaeum, Liège/Austin, pp. 105-119.

DEL FREO, M., M.-L. NOSCH, \& F. ROUGEMONT, 2010 The Terminology of Textiles in the Linear B Tablets, Including Some Considerations on Linear A Logograms and Abbreviations. IN C. Michel \& M.-L. Nosch (Eds.) Textile terminologies in the ancient Near East and Mediterranean from the third to the first millennia BC. Oxford, Oxbow Books: Ch.8

DONADONI ROVERI, A. M., 2001. The art of weaving. Electa, Milano.

DRIEL-MURRAY, C. v., 2000. Leatherwork and skin products. In Ancient Egyptian Materials and Technology. P. T. Nicholson \& I. Shaw, eds., Cambridge University Press, Cambridge, pp. 299319.

EICHER, J. B., 1995. Introduction: Dress as Expression of Ethnic Identity. Dress and Ethnicity: Change Across Space and Time. Oxford, Berg: 1-6

EMERY, I., 1966. The Primary Structures of Fabrics: an Illustrated Classification. The Textile Museum. Washington D.C.

FITTON, J. L. (2002) Minoans. London, British Museum.

FREI, K., SKALS, I., U. MANNERING, M. GLEBA, \& H. LYNGSTRØM, 2009. The Huldremose Iron Age textiles, Denmark: an attempt to define their provenance applying the strontium isotope system. , Journal of Archaeological Science, vol. 36, no. 9: 1965-1971.

GERMER, R., 1992. Die Textilfärberei und die Verwendung gefärbter Textilien im alten Ägypten. Harrassowitz, Wiesbaden. 
GLOB, P.V., 1974. The Mound People; Danish Bronze Age Man Preserved. Book Club Associates, Faber \& Faber, London.

GRABNER, M., A. KLEIN, D. GEIHOFER, H. RESCHREITER, F.E. BARTH, T. SORMAZ \& R. WIMMER, 2007. Bronze age dating of timber from the salt-mine at Hallstatt, Austria.

Dendrochronologia, vol. 24, no. 2-3: 61-68.

GROENMAN-VAN WAATERING, W., 1992. Analysis of the Hides and Skins from the

Hauslabjoch. Jahrbuch des Römisch Germanishcen Zentralmuseums 39.

GRAJETZKI, W. \& S. QUIRKE, 2000. Digital Egypt for Universities. Available online at: .

University College London, accessed $5^{\text {th }}$ November 2010.

GROENMAN-VAN WAATERINGE, W., M. KILIAN, \& H. VAN LONDEN, 1999 The curing of hides and skins in European prehistory. Antiquity, 73: 884-890.

GRÖMER, K. 2005 The Textiles from the prehistoric Salt-mines at Hallstatt (Die Textilien aus dem prähistorischen Salzbergwerk von Hallstatt). IN P. Bichler et al. (Eds.) Hallstatt Textiles: Technical Analysis, Scientific Investigation and Experiments on Iron Age Textiles, Oxford, Archaeopress: 1740

GRÖMER, K. 2007 Bronzezeitliche Gewebefunde aus Hallstatt - Ihr Kontext in der Textilkunde Mitteleuropas und die Entwicklung der Textiltechnologie zur Eisenzeit. Unpublished PhD

Dissertation Institut für Ur- und Frühgeschichte der Universität Wien 2007.

GRÖMER, K. 2009 Rough clothes and high fashion. IN A. Kern et al. (Eds.) Kingdom of Salt; 7000 years of Hallstatt. Vienna, Prehistoric Department, Natural History Museum Vienna: 106-13 GRÖMER, K. 2010 Prähistorische Textilkunst in Mitteleuropa. Geschichte des Handwerkes und Kleidung vor den Römern mit Beiträgen von Regina Hofmann-de Keijzer zum Thema Färben, und Helga Rösel-Mautendorfer zum Thema Nähen. Wien, Naturhistorisches Museum Wien.

HAINES, B. M. 1991 Skin Structure and Leather Properties. In C. Calnan \& B. Haines (Eds.) Leather: its compositions and changes with time, Northampton, The Leather Conservation Centre: $1-11$

HALD, M., 1980. Ancient Danish textiles from bogs and burials: a comparative study of costume and Iron Age textiles. 2nd ed. The National Museum of Denmark, Copenhagen.

HALL, R., 1986. Egyptian Textiles. Shire, Aylesbury.

HAMMARLUND, L., 2004. Handicraft Knowledge Applied to Archaeological Textiles - Fabric Thickness and Density: a Method of Grouping Textiles. Archaeological Textiles Newsletter, 39:711.

HARDING, A. F.,1984. The Mycenaean's and Europe. Academic, London.

HARDING, A. F., 2000. European Societies in the Bronze Age. Cambridge University Press, Cambridge.

HARRIS, S., 2010. Cloth Cultures in Prehistoric Europe; Project Concept and Approach.

Archaeological Textile Newsletter, 50:30-31.

HARRIS,S. 2010 Smooth and Cool, or Warm and Soft; Investigating the Properties of Cloth in Prehistory. In E. Andersson-Strand, M. Gleba, U. Mannering \& C. Munkholt, M. Ringgaard. North European Symposium for Archaeological Textiles $X$ :104-12

HARRIS, S., 2008. Textiles, Cloth, and Skins: The Problem of Terminology and Relationship.

Textile: The Journal of Cloth \& Culture, 6;3: 222-237.

HARRIS, S., 2006. A report on the examination of animal skin artefacts from the Bronze Age salt mines of Hallstatt, Austria, Papers from the Institute of Archaeology, vol. 17: 69-76.

HARRIS, S., H. RÖSEL-MAUTENDORFER, K. GRÖMER, \& H. RESCHREITER, 2010. Cloth Cultures in Prehistoric Europe: the Bronze Age evidence from Hallstatt., Archaeology International, vol. 12, 2008-2009: 22-26.

HAUSER-SCHÄUBLIN, B., 1996. The thrill of the Line, the String, and the Frond, or why the Abelam are a non-cloth culture. Oceania, 67;2: 81-106.

HENRIKSEN, P. S., 2009. Archaeobotanical evidence of flax in prehistoric Denmark., in S. Karg (ed.), Communicating Culture. Workshop Info 1, The Danish Research Council, The Danish National Research Foundation's Centre for Textile, Copenhagen. Available online at 
http://cms.ku.dk/hum-sites/saxo-

sites/projekter/flax/workshop/FLAX_workshop_2009_Abstract_WS1.pdf, accessed 4th March 2010.

HOFMANN-DE KEIJZER, R. \& M.R. VAN BOMMEL, 2009. Colour and colouring. In A. Kern et al. (Eds.) Kingdom of Salt; 7000 years of Hallstatt, Vienna, Prehistoric Department, Natural History Museum Vienna: 112-3

HOOD, S., 2005. Dating the Knossos frescoes. In Aegean wall painting : a tribute to Mark Cameron. vol. 13 L. Morgan, ed., British School at Athens, London: Ch.2.

HORNUNG, E., R. KRAUSS, \& D.A. WARBURTON, 2006a. Chronological Table for the Dynastic Period, in Ancient Egyptian chronology, E. Hornung, R. Krauss, \& D. A. Warburton, eds., Brill, Leiden: 490-498.

HORNUNG, E., R. KRAUSS, \& D. A.WARBURTON, 2006b. King-lists and Manetho's Aigyptiaka, in Ancient Egyptian chronology .E. Hornung, R. Krauss, \& D. A. Warburton, eds., Brill, Leiden.

HORNUNG, E., R. KRAUSS, R., \& D.A. WARBURTON, 2006c. Methods of dating and the Egyptian calendar, in Ancient Egyptian chronology. E. Hornung, R. Krauss, \& D. A. Warburton, eds., Brill, Leiden: 45-51.

IMMERWAHR, S. A., 1990. Aegean painting in the Bronze Age. Pennsylvania State University Press, University Park, Pa, London.

JENSEN, J. 1982, The prehistory of Denmark. London \& New York, Methuen.

JOPLING,C.F. 1975, Yalàlag weaving: Its Aesthetic, Technological and Economic Nexus, IN H.

Lechtman \& R. S. Merrill (Eds.) Material Culture: Style, Organization, and Dynamics of

Technology, New York, West Publishing Co: 211-36.

KEEPER AND STAFF OF THE DEPT. OF ANCIENT EGYPT AND SUDAN, 2007. The British

Museum Book of Ancient Egypt, New Edn. The British Museum, London

KELLOGG, K. 1984, Home Tanning and Leathercraft Simplified. Charlotte, Vermont, Williamson

Publishing Co.

KEMP, B. J. 1989, Ancient Egypt : anatomy of a civilization. London, Routledge.

KEMP, B. J. \& Vogelsang-Eastwood, G., 2001. The ancient textile industry at Amarna (assisted by Andrew Boyce et al.) Egypt Exploration Society, London.

KENDALL ,T. 2007, Egypt and Nubia. In T. Wilkinson (Ed.) The Egyptian world, London,

Routledge: $401-416$

KILLEN, J. T., 2007. Cloth Production in Late Bronze Age Greece: the Documentary Evidence. In Ancient textiles: production, craft and society. Proceedings of the First International Conference on Ancient Textiles, held at Lund, Sweden, and Copenhagen, Denmark on March 19-23, 2003. C.

Gillis \& M.-L. B. Nosch, eds., Oxbow Books, Oxford.

KONTORLI-PAPADOPOULOU, L., 1996. Aegean frescoes of religious character. P. Åströms, Göteborg.

KRISTIANSEN, K. \& LARSSON, T., 2005. The rise of Bronze Age society : travels, transmissions and transformations. Cambridge University Press, Cambridge.

KRUUK, H., 1995. Wild otters: predation and populations. Drawings by Diana Brown. Oxford ; New York, Oxford University Press.

LANG, L. M., 1969. The Palace of Nestor at Pylos in Western Messenia. The Frescoes Princeton University Press, Princeton.

LECHTMAN, H., 1975. Style in Technology - Some Early Thoughts. IN H. Lechtman \& R. S. Merrill (Eds.) Material Culture: Style, Organization, and Dynamics of Technology, New York, West Publishing Co: 3-21.

LEMONNIER, P., 1993. Introduction. IN P. Lemonnier (Ed.) Technological Choices:

Transformation in Material Cultures since the Neolithic, London, Routledge: 1-35.

MALMER, M. P., 1981. A Chorological Study of North European Rock Art. Almqvist \& Wiksell, Stockholm. 
MANDL, F., 2009. The high pastures. In A. Kern et al. (Eds.) Kingdom of Salt; 7000 years of Hallstatt, Vienna, Prehistoric Department, Natural History Museum Vienna: 80-1.

MANNING, S. W., 1999. A test of time: the volcano of Thera and the chronology and history of the Aegean and east Mediterranean in the mid second millennium BC. Oxbow, Oxford.

MANNING, S.W., 2006. Radiocarbon dating and Egyptian chronology. in Ancient Egyptian chronology, E. Hornung, R. Krauss, \& D. A. Warburton, eds., Brill, Leiden: 327-355.

MARCAR, A., 2005. Reconstructing Aegean Bronze Age Fashions. In The clothed body in the ancient world., L. Cleland, M. Harlow, \& L. Llewellyn-Jones, eds., Oxbow, Oxford. MARINATOS, N., 2010. Minoan kingship and the solar goddess: a Near Eastern koine. Urbana, University of Illinois Press.

McCORRISTON, J., 1997. The Fibre Revolution: Textile Extensification, Alientation, and Social Stratification in Ancient Mesopotamia. Current Anthropology, 38, (4) 517-549.

MILITELLO, P., 2007. Textile Industry and Minoan Palaces. In Ancient textiles: production, craft and society. Proceedings of the First International Conference on Ancient Textiles, held at Lund, Sweden, and Copenhagen, Denmark on March 19-23, 2003. C. Gillis \& M.-L. B. Nosch, eds., Oxbow Books, Oxford:36-45.

MOELLER, N., 2007. Urban life. In T. Wilkinson (Ed.) The Egyptian world, London, Routledge: 57-72.

MÖLLER-WIERING, S., 2006. Tools and Textiles- Texts and Contexts Bronze Age textiles found in Crete. Available online at:

http://ctr.hum.ku.dk/research/tools/bronze_age_textiles_found_in_crete.pdf/. The Danish National Research Foundation's Centre for Textile Research University of Copenhagen, accessed on $9^{\text {th }}$ February 2011

MORGAN, L., 1988. The miniature wall paintings of Thera : a study in Aegean culture and iconography. Cambridge University Press, Cambridge.

MOULHÉRAT, C. \& G. SPANTIDAKI, 2009, Cloth from Kastelli, Chania., Arachne, vol. 3:8-15. MOULHÉRAT, C. \& Y. SPANTIDAKI, 2007. Preliminary results from the textiles discovered in Santorini. In North European Symposium for Archaeological Textiles. NESAT IX, 2005 :

Braunwald, Switzerland, Archäologische Textilfunde - Archaeological textiles, A. Rast-Eicher, R. Windler, \& J.-P. Wild, eds., Ennenda, Archeo Tex.

PERINI, R., 1970. Una decorazione sul tessuto dalla palafitta di Ledro. Natura Alpina, XXI,1: 2832.

POPA, G., 2009. Leather, fur and skin - critical raw materials for prehistoric mining. In Kingdom of Salt; 7000 years of Hallstatt. A. Kern et al., eds., Prehistoric Department, Natural History Museum Vienna, Vienna, pp. 102-105.

PRESTON, L., 2008. Late Minoan II and IIIB Crete. In C. W. Shelmerdine (Ed.) The Cambridge companion to the Aegean Bronze Age, New York, Cambridge University Press: 310-326.

PREZIOSI, D. \& L. A. HITCHCOCK,1999. Aegean art and architecture. Oxford University Press, Oxford.

PRITCHARD, F., 2006. Clothing culture: dress in Egypt in the first millennium AD: clothing from Egypt in the collection of the Whitworth Art Gallery, the University of Manchester. Manchester, Whitworth Art Gallery.

RANDSBORG, K., 2011. Bronze Age Textiles; Men, Women and Wealth. London, Bristol Classical Press.

RANDSBORG, K., 2006. Opening the Oak-coffins; New Dates -New Perspectives, Acta Archaeologica, vol. 77:3-162.

RASMUSSEN, M. \& C. ADAMSEN, 1993. Settlement. In S. Hvass \& B. Storgaard (Eds.) Digging into the past : 25 years of archaeology in Denmark [translation: John Hines]., Aarhus, Royal Society of Northern Antiquaries, Aarhus Universitetsforlag, Jutland Archaeological Society:136-44. RAST-EICHER, A., 2005. Bast before Wool: the first textiles. In P. Bichler et al. (Eds.) Hallstatt Textiles: Technical Analysis, Scientific Investigation and Experiments on Iron Age Textiles, Oxford, Archaeopress: 117-31. 
RESCHREITER, H., 2005. Die prähistorischen Salzbergbaue in Hallstatt und ihre Textilreste (The prehistoric Salt-mines at Hallstatt and its Textile remains). In P. Bichler et al. (Eds.) Hallstatt Textiles: Technical Analysis, Scientific Investigation and Experiments on Iron Age Textiles, Oxford, Archaeopress:11-6.

RESCHREITER, H. \& K. KOWARIK, 2009a. Puzzling buildings. In A. Kern et al. (Eds.) Kingdom of Salt; 7000 years of Hallstatt, Vienna, Prehistoric Department, Natural History Museum

Vienna:72-3.

RESCHREITER, H. \& K. KOWARIK, 2009b. Puzzling gaps. In A. Kern et al. (Eds.) Kingdom of Salt; 7000 years of Hallstatt, Vienna, Prehistoric Department, Natural History Museum Vienna:701 .

RESCHREITER, H. \& K. KOWARIK, K., 2009c. The 'Heidengebirge'. IN A. Kern et al. (Eds.)

Kingdom of Salt; 7000 years of Hallstatt, Vienna, Prehistoric Department, Natural History Museum Vienna:36-9.

RESCHREITER, H. \& K. KOWARIK, 2009d. The Bronze Age initiative., in Kingdom of Salt; 7000 years of Hallstatt. A. Kern et al., eds., Prehistoric Department, Natural History Museum Vienna, Vienna, pp. 48-64.

RESCHREITER, H., 2005. Die prähistorischen Salzbergbaue in Hallstatt und ihre Textilreste (The prehistoric Salt-mines at Hallstatt and its Textile remains). In Hallstatt Textiles: Technical Analysis, Scientific Investigation and Experiments on Iron Age Textiles. P. Bichler et al., eds., Archaeopress, Oxford, pp. 11-16.

ROBINS, G., 2007, Art. In T. Wilkinson (Ed.) The Egyptian world, London, Routledge:355-365

ROEHRIG,C.H., 1996. Women's work: Some occupations of nonroyal women as depicted in ancient Egyptian art. In Mistress of the House, Mistress of Heaven: women in ancient Egypt., A. K. Capel \& G. E. Markoe, eds., Hudson Hills Press in association with Cincinnati Art Museum, New York:

ROUGEMONT, F., 2007. Flax and Linen Textiles in the Mycenaean Palatial Economy. In Ancient textiles: production, craft and society. Proceedings of the First International Conference on Ancient Textiles, held at Lund, Sweden, and Copenhagen, Denmark on March 19-23, 2003. C. Gillis \& M.L. B. Nosch, eds., Oxbow Books, Oxford: 46-49.

RYDER,M. 1988, Danish Bronze Age Wools. Journal of Danish Archaeology, vol.7:136-143. RYDER, M.,1992. Iron Age, haired, animal skins from Hallstatt, Austria. Oxford Journal of Archaeology, 11, (1): 55-67.

RYDER, M. L., 1990. Skin and wool remains from Hallstatt. Mitteilungen der Anthropologischen Gesellschaft in Wien, vol. 120: 103-112.

RYDER, M. L., 2005. The Human Development of Different Fleece-Types in Sheep and Its Association with the Development of Textile Crafts. In North European Symposium for Archaeological Textiles (7th : 1999 : Edinburgh, Scotland): Northern archaeological textiles: NESAT VII / textile symposium in Edinburgh, 5th-7th May 1999 ; F. Pritchard \& J.-P. Wild, eds., Oxbow Books, Oxford:122-128.

RYHOLT, K., 2006. The Turin King-List or so-called Turin Canon (TC) as source for chronology. In Ancient Egyptian chronology. E. Hornung, R. Krauss, \& D. A. Warburton, eds., Brill, Leiden: 26-32.

SCHLUMBAUM, A., P. F. CAMPOS, S. VOLKEN, M. VOLKEN, A. HAFNER, \& J.

SCHIBLER, 2010. Ancient DNA, a Neolithic legging from the Swiss Alps and the early history of goat. Journal of Archaeological Science, XXX: 1-5.

SCHNEIDER, J. \& A. WEINER, 1986. Introduction. In A. B. Weiner \& J. Schneider (ed.) Cloth and Human Experience, Washington \& London, Smithsonian Institute Press.

SCHOFIELD, L., 2007. The Mycenaean's British Museum Press, London.

SHAPLAND, A. 2010. The Minoan Lion: presence and absence on Bronze Age Crete, World Archaeology, 42;2: 273-289. 
SHERRATT, A. 1981. Plough and pastoralism: aspects of the secondary products revolution. In I. Hodder, G. Isaac, \& N. Hammon (Eds.) Patterns of the Past, Cambridge, Cambrige University Press: 261-305.

SHERRATT , A., 1993 What would a Bronze-Age world system look like? Relations between temperate Europe and the Mediterranean in later prehistory, Journal of European Archaeology 1 (2): $1-57$.

SØRENSEN, M.L.S., 1997. Reading dress: the construction of social categories and identities in Bronze Age Europe. Journal of European Archaeology, 5 (1): 93-114.

SPALINGER, A., 2007. The army. In T. Wilkinson (Ed.) The Egyptian world, London, Routledge:118-28.

SPENCE, K., 2007. Architecture. In T. Wilkinson (Ed.) The Egyptian world, London, Routledge:366-87

SPINDLER, K., 1995. The Man in the Ice; The preserved body of a Neolithic man reveals the secrets of the Stone Age London, Phoenix.

STANLEY SMITH, C., 1970. The Cover Design. Art, Technology, and Science: Notes on Their Historical Interaction. Technology and Culture, 11, (4): 493-549.

STEEL,L., 2007, Egypt and the Mediterranean World, IN T. Wilkinson (Ed.) The Egyptian world, London, Routledge: 459-475.

SUNDSTRÖM, A., 2009. A Bronze Age Plaited Starting Border. In North European Symposium for Archaeological Textiles X. vol. 5 E. Andersson Strand et al., eds., Oxbow Books, Oxford: 233243.

SZEVERENYI, V., 2004. The early and middle Bronze Ages in Central Europe. In P. Bogucki \& P. J. Crabtree (Eds.) Ancient Europe 8000 B.C.-A.D. 1000 : encyclopedia of the Barbarian world. New York ; London, Thompson/Gale.

TIDOW, K., 1992. Wollengewebe aus dem Bronzezeitlichen Baumsargfund von Harrislee bei Flensburg. In Textiles in European Archaeology: Report from the 4th NESAT Symposium, 1-5 th may 1990 in Copenhagen, vol. 5 L. Bender Jørgensen \& E. Munksgaard, eds., Konservatorskolen Det Kongelige Danske Kunstakademi, Copenhagen: 31-36.

TITE, M. S. \& B. SILLAR, 2000. The Challenge of "Technological Choices" for Materials Science Approaches in Archaeology. Archaeometry, 42, (1): 2-20.

TRNKA, E., 2007. Similarities and Distinctions of Minoan and Mycenaean Textiles. In Ancient textiles: production, craft and society. Proceedings of the First International Conference on Ancient Textiles, held at Lund, Sweden, and Copenhagen, Denmark on March 19-23, 2003, C. Gillis \& M.L. B. Nosch, eds., Oxbow Books, Oxford:127-129.

TYSON SMITH,S. 2007. Ethnicity and Culture, In T. Wilkinson (Ed.) The Egyptian world. London, Routledge: 218-241.

VANDKILDE, H., 2004, Bronze Age Scandinavia. In P. Bogucki \& P. J. Crabtree (Eds.) Ancient Europe 8000 B.C.-A.D. 1000: encyclopedia of the Barbarian world. New York; London, Thompson/Gale.

VANDKILDE, H., 1996. From stone to bronze : the metalwork of the late neolithic and earliest bronze age in Denmark, with a contribution by Peter Northover. Moesgard, Aarhus, Jutland Archaeological Society.

VANDKILDE, H., U. RAHBEK, \& K.L. RASMUSSEN, 1996. Radiocarbon dating and the chronology of Bronze Age Southern Scandinavia, in Absolute chronology : archaeological Europe 2500-500 BC, vol. 67 K. Randsborg, ed., Acta archaeologica, København : Munksgaard: 183-198. VELDMEIJER, A. \& E. ENDENBURG, 2007. Amarna leatherwork in the Berlin Museum, Egyptian Archaeology. vol. 31: 36-37.

VELDMEIJER, A. J., 2010. Amarna's leatherwork. Part I, Preliminary analysis and catalogue, Druk Ware, Norg, The Netherlands.

VOGELSANG-EASTWOOD, G., 1992. The production of linen in pharaonic Egypt. Leiden, Textile Research Centre. 
VOGELSANG-EASTWOOD, G., 1993. Pharaonic Egyptian clothing. E.J. Brill, Leiden ; New York.

VOGELSANG-EASTWOOD, G., 1999. Tutankhamun's wardrobe: garments from the tomb of Tutankhamun. With illustrations by Martin Hense and Kelvin Wilson. Barjesteh van Waalwijk van Doorn \& Co., Rotterdam.

VOGELSANG-EASTWOOD, G., 2000. Textiles. In Ancient Egyptian Materials and Technology, P. T. Nicholson \& I. Shaw, eds., Cambridge University Press, Cambridge: Ch.11

WALTON, P. \& G. EASTWOOD, 1988. A Brief Guide to the Cataloguing of Archaeological Textiles, 4 ed. London, Institute of Archaeology.

WARDLE, K. A., 1994. The Palace Civilizations of Minoan Crete and Mycenaean Greece 20001200 BC. In B. Cunliffe (Ed.) The Oxford illustrated prehistory of Europe., Oxford, New York, Oxford University Press.

WARREN, P., 1996. The Aegean and the limits of radiocarbon dating. Acta Archaeologica, vol. 67, pp.283-290.

WEES,

WILD, J-P. 2003. Anatolia and the Levant in the Neolithic and Chalcolithic periods,c.80003500/3300 BC. In, D. Jenkins (eds) The Cambridge History of Western Textiles, Cambridge, Cambridge University Press: 39-43.

WILKINSON,T., 2007. Egypt and Mesopotamia, In T. Wilkinson (Ed.) The Egyptian world, London, Routledge:449-475.

WINIGER, J., 1995. Die Bekleidung des Eismannes und die Anfänge der Weberei nördlich der Alpen. IN K. Spindler et al. (Eds.) Der Mann im Eis, Neue Funde und Ergebnisse, vol. 2 , Wien \& New York, Springer-Verlag:119-88.

WOBST, H. M., 1977. 'Stylistic behaviour and information exchange'. In C. E. Cleland (Ed.) For the Director: Research Essays in Honor of James B. Griffin, 61 ed. vol. 61, Michigan, Ann Arbor: 317-342

\section{Biographical note}

Susanna Harris wrote her PhD on 'Cloth in Prehistoric Societies. The social context of cloth in prehistory, with case studies from northern Italy and the Alpine region from the Neolithic to Bronze Age' at the Institute of Archaeology, UCL. She is currently British Academy Post-doctoral Fellow at the same institution, researching 'Cloth Cultures in Prehistoric Europe', focusing on the relationship between textiles and animal skins. Her research interests include interdisciplinary approaches to research methods, experimental archaeology and world-wide rock art. These are reflected in her co-organisation of the conference 'Wrapping and Unwrapping the Body Archaeological and Anthropological perspectives' at the Institute of Archaeology, UCL in May 2010 and the session 'Threads to the past: novel methods for the investigation of archaeological textiles and other organic materials' at the EAA annual meeting in The Hague, September 2010. 


\section{Figures \& tables}

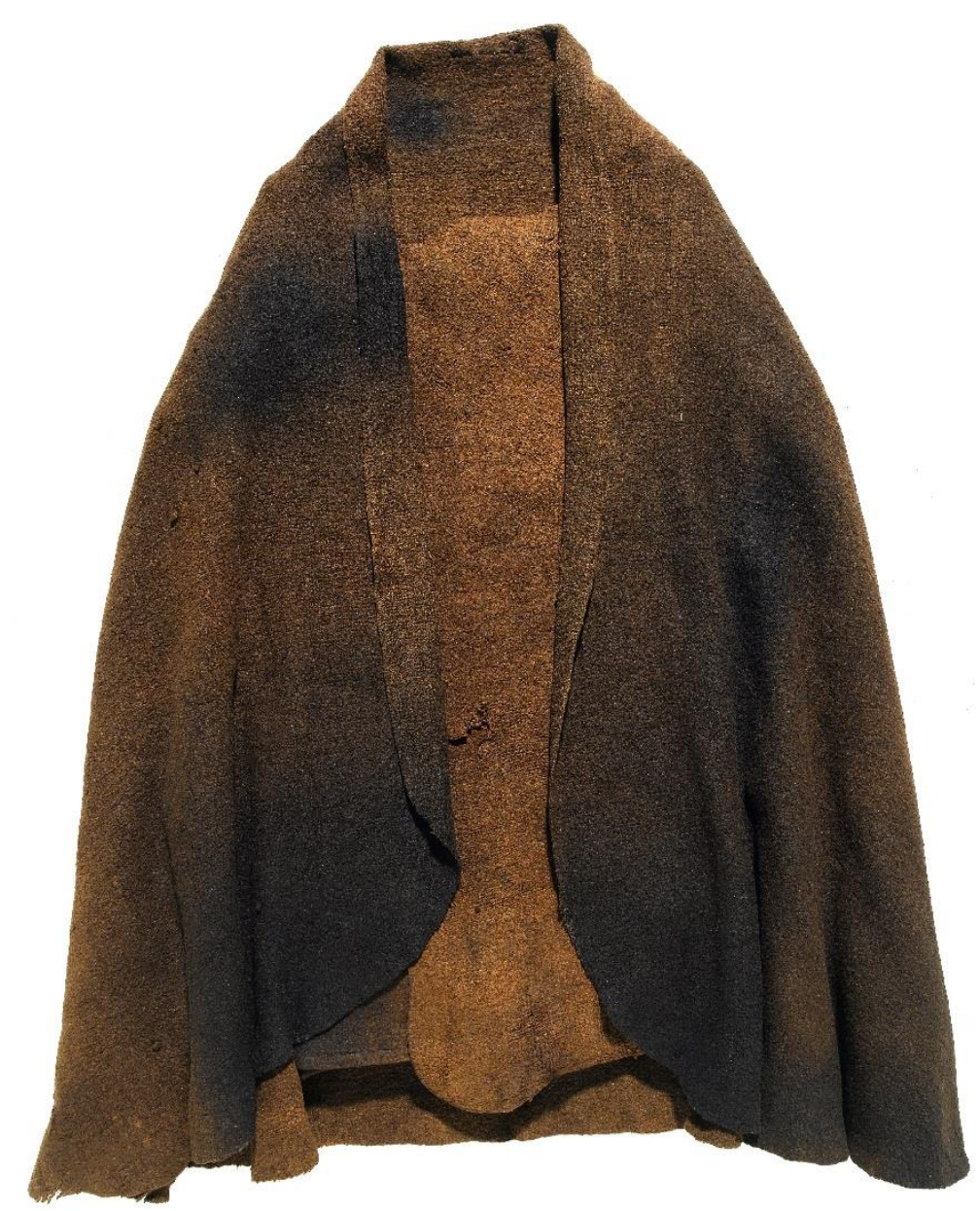

Figure 1. Wool textile gown and cloak from a man's burial at Muldbjerg, Denmark. Photo courtesy of Roberto Fortuna, the National Museum of Denmark.

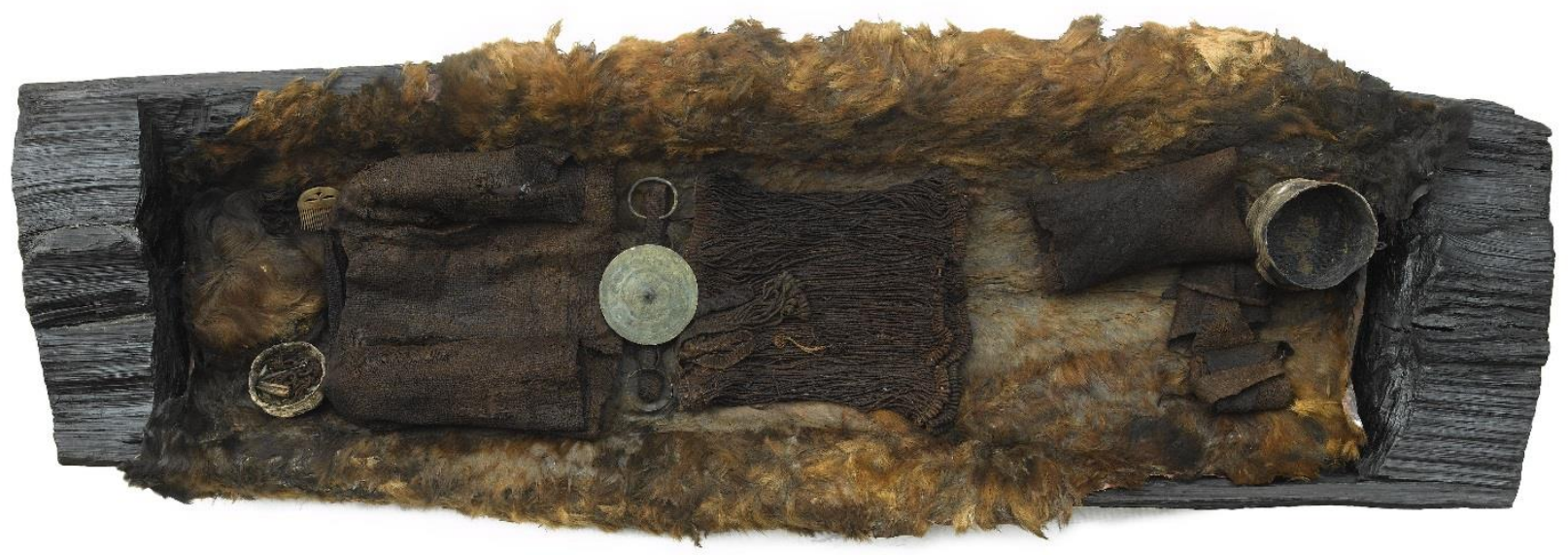

Figure 2. Wool blouse, foot wraps and cloth in plain weave, corded skirt, narrow repp belt with tassel, all laid on a cow skin from a woman's burial at Egtved, Denmark. Photo courtesy of Roberto Fortuna, the National Museum of Denmark. 

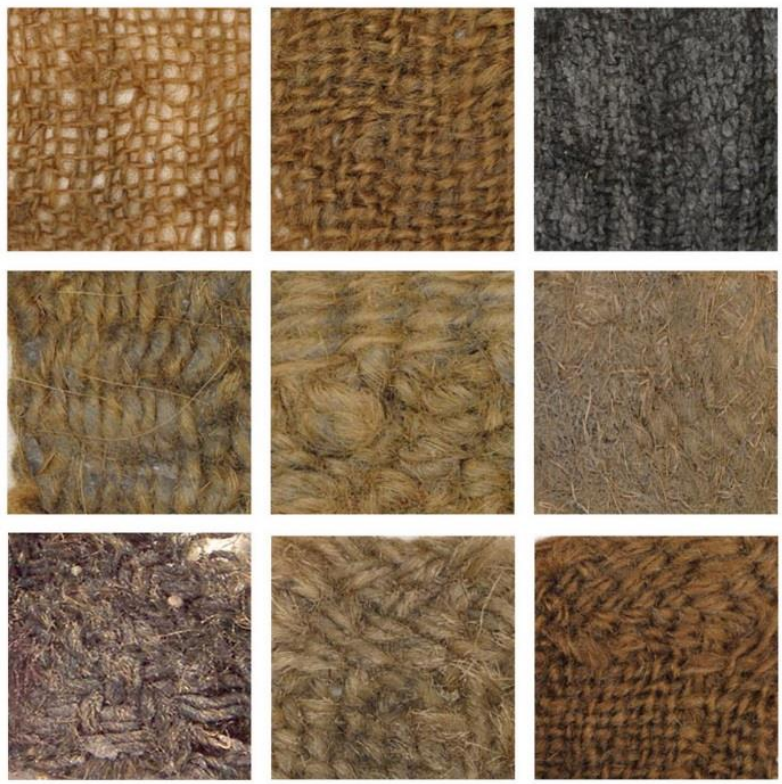

Figure 3. Textiles showing a variety of fabric structures and weave densities, from the Bronze Age Hallstatt salt mines, Austria. Photo courtesy of A. Rausch, Naturhistorisches Museum, Vienna.

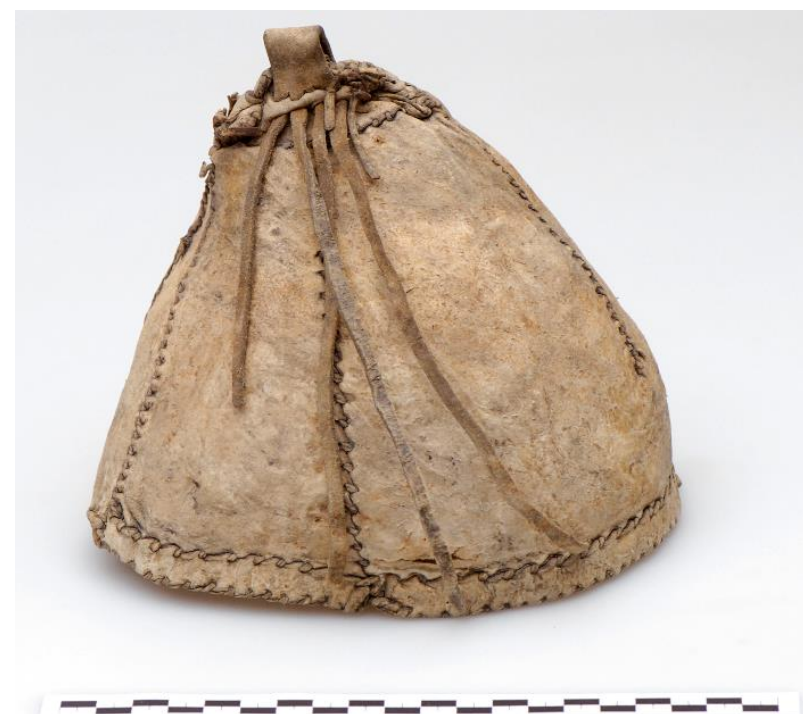

Figure 4. Conical hat with tassel, animal skin with the fur facing inward from the Grünerwerk area of the Hallstatt salt mines, Austria. Photo courtesy of A. Rausch, Naturhistorisches Museum, Vienna.

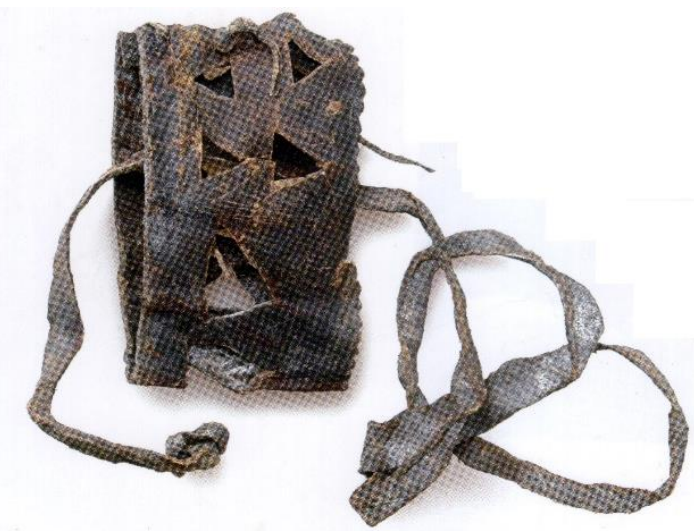

Figure 5. Bracelet or wrist strap with zigzag edge, cut work and scoring from the Christian von Tuschwerk area of the Hallstatt salt mines, Austria. Photo courtesy of A. Rausch, Naturhistorisches Museum, Vienna 


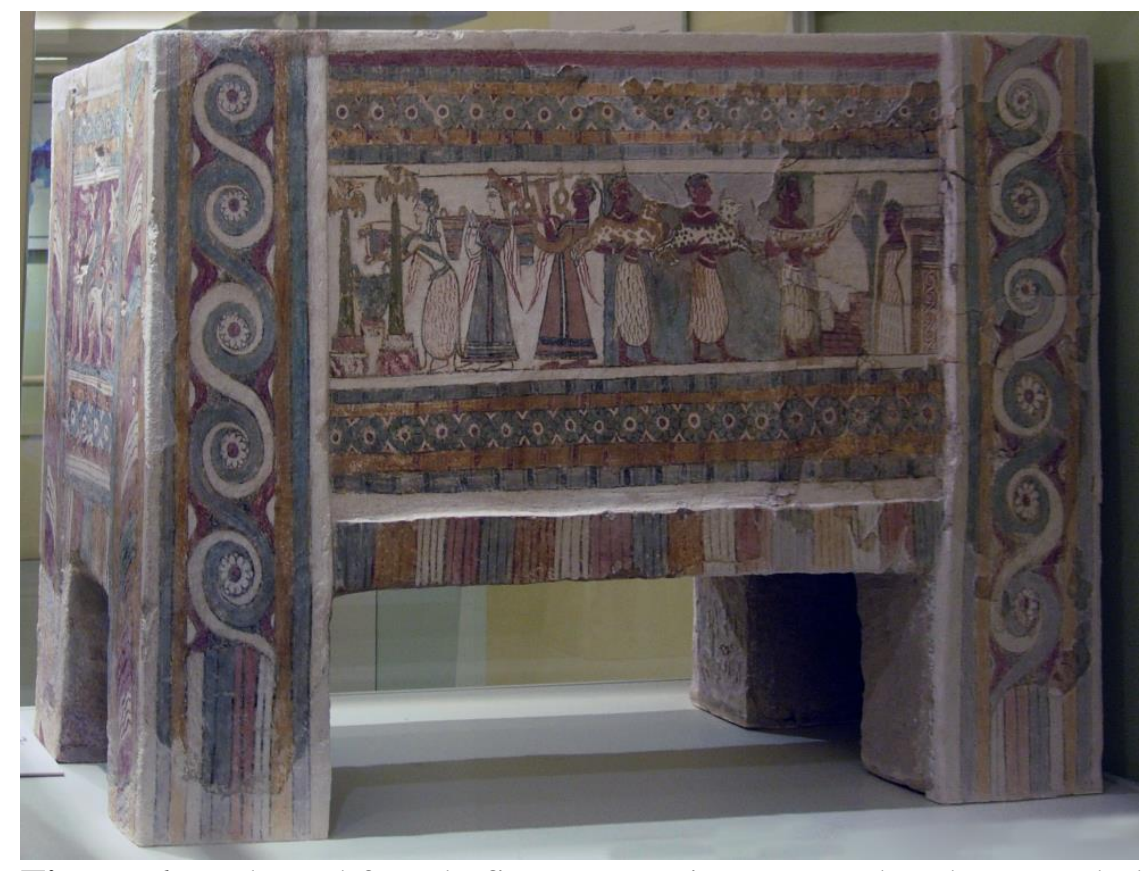

Figure 6. Male and female figures wearing pattered and textured clothing on a sarcophagus from Agia Triada, Crete. Four of the figures wear the hide or fleece skirt, with shaggy texture and shaped hem. A similar texture is shown on the upper surface of the figure far right. Two figures wear long, coloured tunics with striped edges and one wears a short-sleeved top with contrasting edges. Photograph S. Harris.

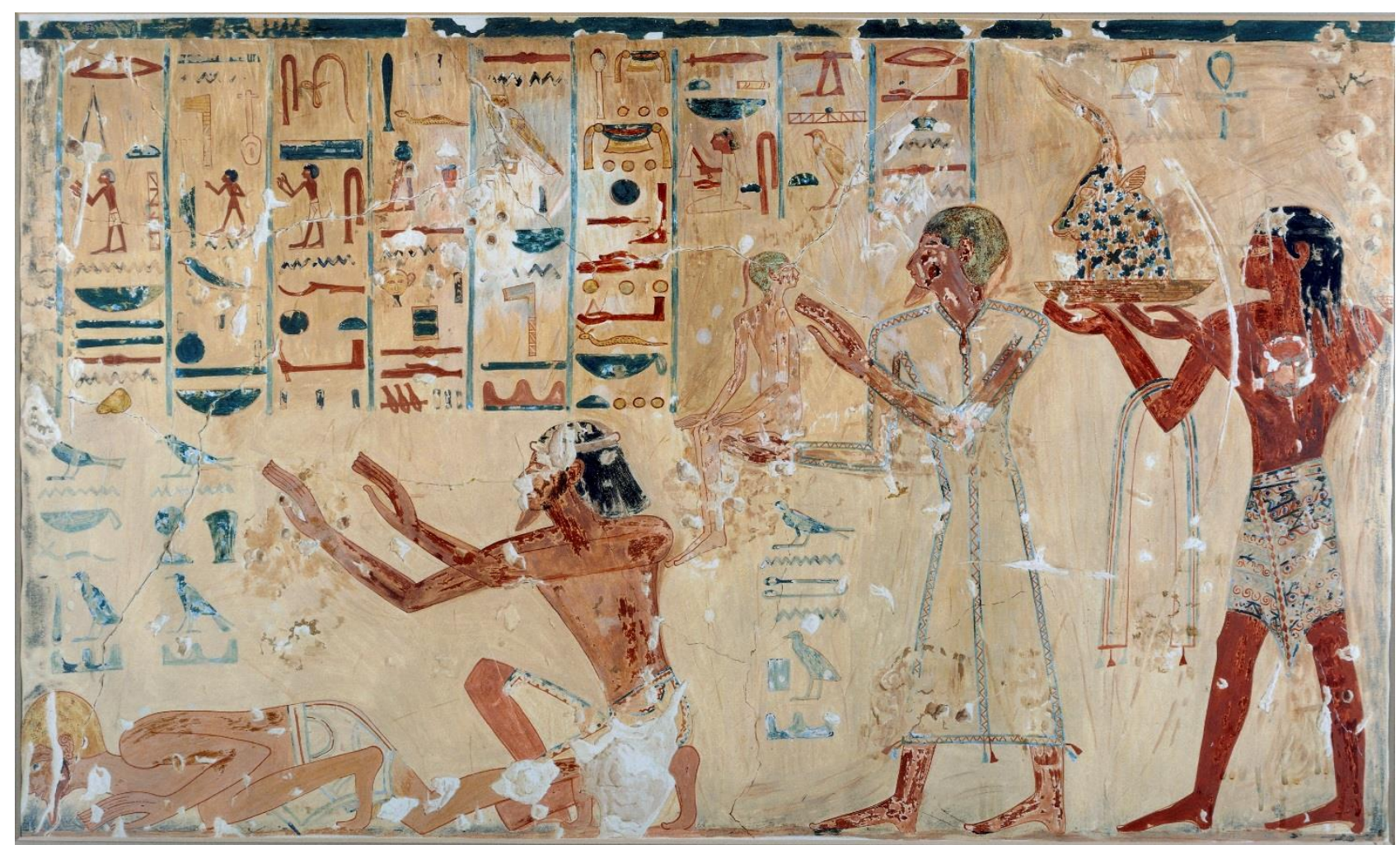

Figure 7. Facsimile of a wall painting from the tomb of Menkheperraseneb (Theban Tomb 86), Thebes, Egypt showing foreigners in a procession. The text identifies the figures on the far right as from Keftiu. He wears a coloured, pattern loincloth, and carries a striped, tasselled textile across one arm and a bull's head (C) Trustees of the British Museum. 


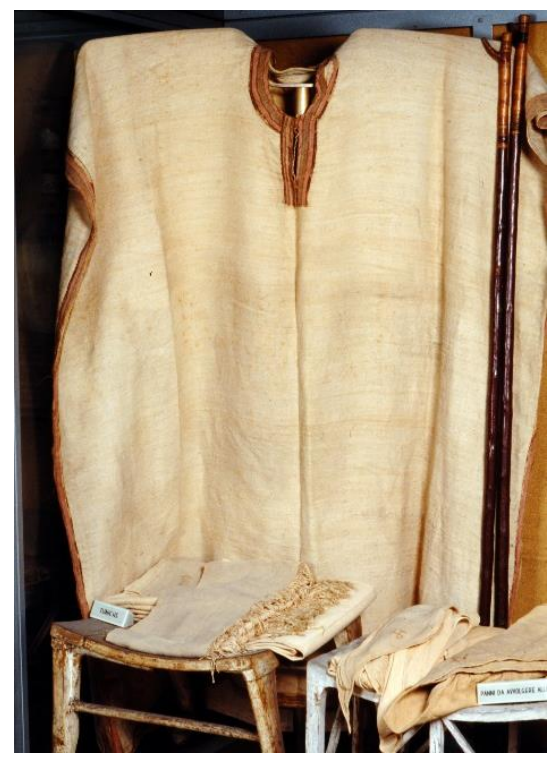

Figure 8. Dense, plain weave, linen tunic with coloured repp band from the tomb of Kha and Merit (Theban Tomb 8), Deir el Medina, Egypt. Photo courtesy of The Museum of Turin.

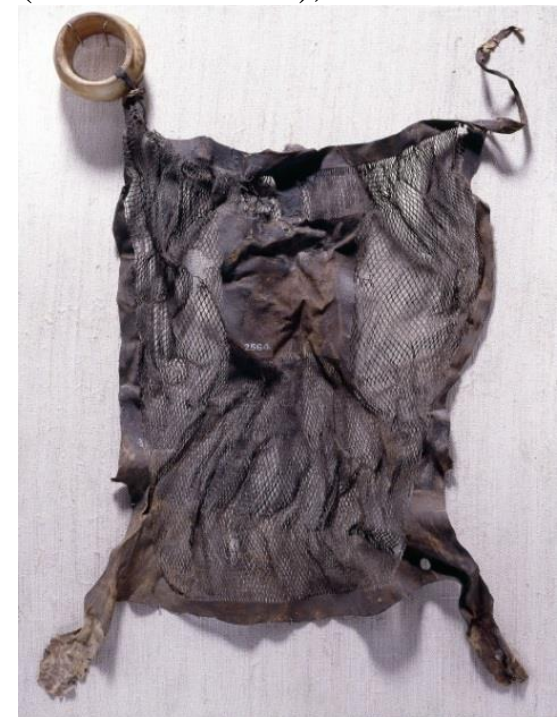

Figure 9. Fine-mesh slit work, leather loincloth, Egypt. (C) Trustees of the British Museum.

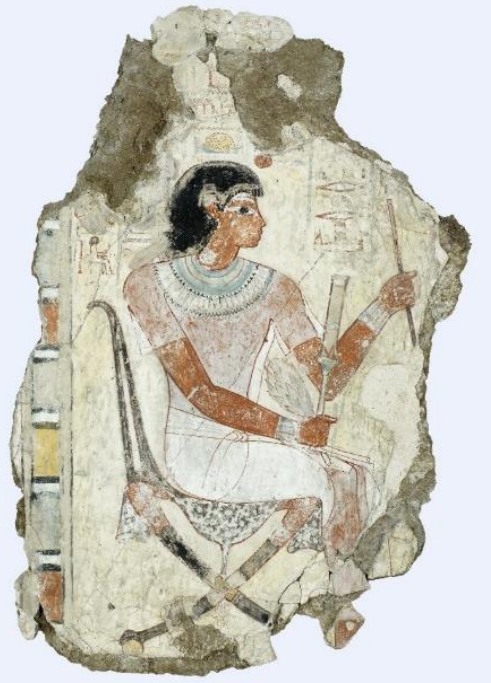

Figure 10. Fragment of wall painting from the tomb of Nebamun (Theban Tomb 63), Thebes, Egypt. Nebamun is dressed in white, sat on a chair with dappled animal skin seat cover. His tunic is semi-transparent in contrast to the dense, white kilt showing the varied visual density of linen textiles $($ ) The Trustees of the British Museum 


\begin{tabular}{|c|c|c|c|}
\hline & Figure & Technical description & Appearance \\
\hline Plain weave & 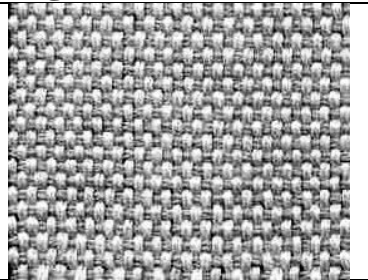 & $\begin{array}{l}\text { Threads are interlaced one over, one } \\
\text { under, alternating each row. }\end{array}$ & $\begin{array}{l}\text { Flat surface, } \\
\text { smooth or open } \\
\text { depending on the } \\
\text { density. }\end{array}$ \\
\hline Basket weave & 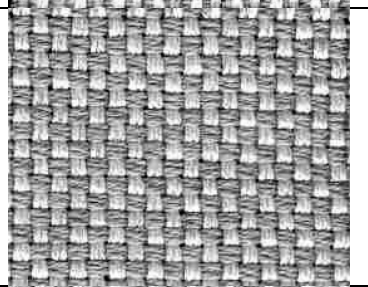 & $\begin{array}{l}\text { Like plain weave, but with two } \\
\text { threads worked together. }\end{array}$ & $\begin{array}{l}\text { Similar to plain } \\
\text { weave, but } \\
\text { double threads } \\
\text { visible. }\end{array}$ \\
\hline Twill & 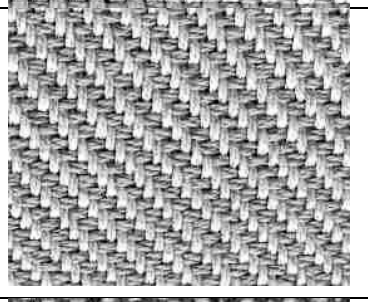 & $\begin{array}{l}\text { Threads are interlaced one or more } \\
\text { over, followed by one or more } \\
\text { under; the sequence is staggered in } \\
\text { subsequent rows. The figure is a } 2 / 2 \\
\text { twill, referring to the two under, } \\
\text { two over pattern repeat. }\end{array}$ & $\begin{array}{l}\text { Diagonal pattern } \\
\text { or texture. }\end{array}$ \\
\hline $\begin{array}{l}\text { Twill } \\
\text { variations }\end{array}$ & 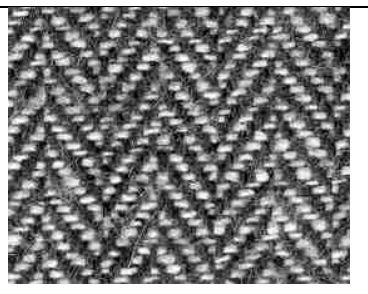 & $\begin{array}{l}\text { Variations of twill use more } \\
\text { complex sequences of interlacing. } \\
\text { This figure shows broken twill } \\
\text { where the patterned effect is } \\
\text { amplified by the use of different } \\
\text { colour threads. }\end{array}$ & $\begin{array}{l}\text { Zigzag pattern or } \\
\text { texture. }\end{array}$ \\
\hline $\begin{array}{l}\text { Repp (warp or } \\
\text { weft facing) }\end{array}$ & 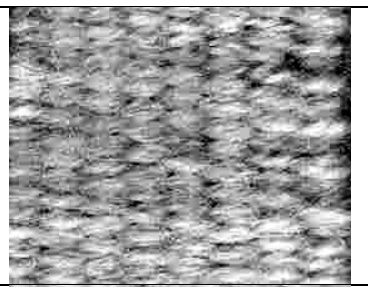 & $\begin{array}{l}\text { Like plain weave, but one set of } \\
\text { threads is worked more densely. In } \\
\text { this figure the dense threads } \\
\text { completely cover the threads in the } \\
\text { opposite direction. }\end{array}$ & $\begin{array}{l}\text { Slight or } \\
\text { pronounced } \\
\text { ribbed effect. }\end{array}$ \\
\hline $\begin{array}{l}\text { Tapestry } \\
\text { weave }\end{array}$ & & $\begin{array}{l}\text { Like plain weave, but coloured } \\
\text { threads are woven in to create } \\
\text { patterns and motifs. The photograph } \\
\text { shows tapestry weave in repp. }\end{array}$ & $\begin{array}{l}\text { Patterns and } \\
\text { motifs. }\end{array}$ \\
\hline
\end{tabular}

Table 1. The main fabric structures. The photographs show modern examples of weaving and are worked in a variety of wool and plant fibre threads of different thicknesses and densities. 


\begin{tabular}{|c|c|c|c|c|}
\hline & $\begin{array}{l}\text { Southern Scandinavian cloth } \\
\text { cultures }\end{array}$ & $\begin{array}{l}\text { Cloth cultures and the Hallstatt } \\
\text { salt mine }\end{array}$ & Cloth culture in the Aegean & Cloth cultures in Egypt \\
\hline Textile fibres & Sheep's wool* & Wool*, linen & $\begin{array}{l}\text { Sheep's wool, goat hair\#, linen, } \\
\text { nettle\# }\end{array}$ & Sheep's wool, goat hair \#, linen* \\
\hline Fabric structures & $\begin{array}{l}\text { Plain weave*, repp, repp with } \\
\text { extended fringe, plain weave with } \\
\text { sewn pile }\end{array}$ & $\begin{array}{l}\text { Plain weave*, repp, half basket } \\
\text { weave, } 2 / 1 \text { twill, pointed twill }\end{array}$ & $\begin{array}{l}\text { Plain weave, repp, } \\
\text { plain weave with } \\
\text { supplementary warp or weft, } \\
\text { twill, tapestry weave }\end{array}$ & $\begin{array}{l}\text { Plain weave*, repp, basket weave, } \\
\text { half basket weave, tapestry weave, } \\
\text { plain weave with knotted or looped } \\
\text { pile \# }\end{array}$ \\
\hline Thread count & 1.8-7.5 threads per $\mathrm{cm}$ & 5-24 threads per $\mathrm{cm}$ & $\begin{array}{l}10-20 \text { threads per } \mathrm{cm} \\
\text { (wider range expected, see text) }\end{array}$ & $5-100$ threads per $\mathrm{cm}$. \\
\hline $\begin{array}{l}\text { Decoration and } \\
\text { finish on textiles }\end{array}$ & $\begin{array}{l}\text { No dye analysis to date, differently } \\
\text { pigmented wool, } \\
\text { fringes on } 2 \text { edges, } \\
\text { fulled surfaces. }\end{array}$ & $\begin{array}{l}\text { Colour: red, blue, yellow. } \\
\text { twill textured effect, } \\
\text { fulled surfaces. }\end{array}$ & $\begin{array}{l}\text { Colour: red, blue, yellow, } \\
\text { brown, grey. } \\
\text { Fringes, stripes, patterned } \\
\text { bands, motifs }\end{array}$ & $\begin{array}{l}\text { Colour: red, blue, yellow, green, } \\
\text { brown, black. Bleaching. } \\
\text { Fringes on 2-3 edges, embroidery, } \\
\text { appliqué, stripes, pleating }\end{array}$ \\
\hline Species of skins & Cow*, sheep. goat, deer, otter\# & $\begin{array}{l}\text { Cow*, sheep*, goat*, chamois, } \\
\text { ibex, dog and other fur-bearing } \\
\text { species }\end{array}$ & Cow, sheep, goat & $\begin{array}{l}\text { Cow, sheep, goat, gazelle, leopard, } \\
\text { cheetah }\end{array}$ \\
\hline $\begin{array}{l}\text { Decoration and } \\
\text { finish on skins }\end{array}$ & Haired*, depilated & $\begin{array}{l}\text { Haired*, depilated, cut work \#, } \\
\text { scoring }\end{array}$ & Haired, depilated & $\begin{array}{l}\text { Haired, depilated, cut work, } \\
\text { colour, appliqué, embossed }\end{array}$ \\
\hline Use of textiles & Clothing, shrouds, blankets & Hauling sacks, clothing, rags & Clothing & $\begin{array}{l}\text { Clothing, shrouds, mummy } \\
\text { wrappings, statue wraps, ritual } \\
\text { cloth, canopies, bedding, jar } \\
\text { covers, sling shots, quivers }\end{array}$ \\
\hline Use of skins & $\begin{array}{l}\text { Shroud, shoes, straps, } \\
\text { folding stool seat, } \\
\text { sword sheath lining }\end{array}$ & $\begin{array}{l}\text { Hat, hand leathers, carry sack, } \\
\text { cushion, finger bandages, wrist } \\
\text { bands or bracelet, straps, rags. }\end{array}$ & $\begin{array}{l}\text { Shields, folding stool seat, } \\
\text { chariot component, armour, } \\
\text { greaves, wrist bands }\end{array}$ & $\begin{array}{l}\text { Shields, loincloths, footwear, } \\
\text { arrow quivers, armour, straps, } \\
\text { balls, stool seat, chariot } \\
\text { components. }\end{array}$ \\
\hline Key references & $\begin{array}{l}\text { (Bender Jørgensen 1986; } \\
\text { Bergerbrant 2007; Broholm \& Hald } \\
\text { 1940; Ryder 1988) }\end{array}$ & $\begin{array}{l}\text { (Barth 1992; Grömer 2007,2010, } \\
\text { Harris 2006; Popa 2009; Ryder } \\
\text { 1990) }\end{array}$ & $\begin{array}{l}\text { (Barber 1991:317-28, Burke } \\
\text { 2010; Immerwahr 1990, } \\
\text { Möller-Wiering 2006, } \\
\text { Moulhérat \& Spantidaki 2007) }\end{array}$ & $\begin{array}{l}\text { (Driel-Murray 2000; Kemp \& } \\
\text { Vogelsang-Eastwood 2001; } \\
\text { Vogelsang-Eastwood } \\
\text { 1992,1993,1999,2000; Veldmeijer } \\
\text { 2010) }\end{array}$ \\
\hline
\end{tabular}

Table 2. Cloth cultures compared by materials and use. Key: Dominant features are indicated with *, features that are present but not common are indicated with \#, features suggested through inference in italics. 
${ }^{1}$ To avoid repeating that the different nomenclature Bronze Age for Europe and New Kingdom for Egypt, from now on when I refer to the Bronze Age I am including the New Kingdom of Egypt.

${ }^{2}$ A rectangular cloth with simple neck hole and sides sewn up to the armpit. 